\title{
Direct Control of Stem Cell Behavior Using Biomaterials and Genetic Factors
}

\author{
Jeong-Kee Yoon, ${ }^{1,2}$ Mi-Lan Kang, ${ }^{2}$ Joo Hyun Park, ${ }^{3}$ Kyoung-Mi Lee, ${ }^{2,4}$ Young Min Shin, ${ }^{2}$ \\ Jin Woo Lee, ${ }^{2,4}$ Hyun Ok Kim $\mathbb{D}^{5},{ }^{5}$ and Hak-Joon Sung $\mathbb{D}^{2,6}$
}

${ }^{1}$ Division of Cardiology, Severance Cardiovascular Hospital, Yonsei University College of Medicine, Seoul, Republic of Korea

${ }^{2}$ Severance Biomedical Science Institute, College of Medicine, Yonsei University, Seoul, Republic of Korea

${ }^{3}$ Department of Obstetrics and Gynecology, Yonsei University College of Medicine, Seoul, Republic of Korea

${ }^{4}$ Department of Orthopaedic Surgery, Yonsei University College of Medicine, Seoul 120-752, Republic of Korea

${ }^{5}$ Department of Laboratory Medicine, Yonsei University College of Medicine, Seoul, Republic of Korea

${ }^{6}$ Department of Mechanical Engineering, Georgia Institute of Technology, Atlanta, GA, USA

Correspondence should be addressed to Hak-Joon Sung; hj72sung@yuhs.ac

Received 2 December 2017; Revised 5 February 2018; Accepted 4 April 2018; Published 10 May 2018

Academic Editor: Açelya Yilmazer

Copyright (C 2018 Jeong-Kee Yoon et al. This is an open access article distributed under the Creative Commons Attribution License, which permits unrestricted use, distribution, and reproduction in any medium, provided the original work is properly cited.

\begin{abstract}
Stem cells have recently emerged as an important candidate for cell therapy. However, some major limitations still exist such as a small quantity of cell supply, senescence, and insufficient differentiation efficiency. Therefore, there is an unmet need to control stem cell behavior for better clinical performance. Since native microenvironment factors including stem cell niche, genetic factors, and growth factors direct stem cell fate cooperatively, user-specified in vitro settings are required to understand the regulatory roles and effects of each factor, thereby applying the factors for improved cell therapy. Among others, various types of biomaterials and transfection method have been employed as key tools for development of the in vitro settings. This review focuses on the current strategies to improve stemness maintenance, direct differentiation, and reprogramming using biomaterials and genetic factors without any aids from additional biochemicals and growth factors.
\end{abstract}

\section{Introduction}

Stem cell therapy possesses significant advantages compared to conventional cell therapy using mature cells, as stem cells are more accessible and obtainable, are easy to culture and expand, and enable avoiding graft-versus-host rejection [1-3]. With such merits, stem cells have emerged as a candidate for cell therapy since 1968 when bone marrow transplantation surgery was conducted. Stem cells can selfrenew and further differentiate into specific lineages upon stimulation. Among many kinds of stem cells, adult stem cells, represented by mesenchymal stem cells (MSCs), can be isolated or derived from many kinds of tissues and thus possess similar but different properties from each other. In a native microenvironment, MSCs are surrounded by stem cell niches composed of extracellular matrix (ECM) and growth factors. These microenvironment factors play instructive roles in directing stem cell behavior such as growth, lineage commitment, and stemness maintenance.

For clinical applications, stem cells have to be expanded because only a limited number of cells can be extracted from a tissue source. Moreover, when stem cells are expanded in a series of exhausted in vitro culture, the efficacy of their proliferation and differentiation decreases due to a progressive loss of stemness driven by senescence. To overcome such problems, state-of-the-art technologies using biomaterials, genetic factors, and growth factors which can mimic a native microenvironment or improve stem cell behavior have been employed recently. In conventional studies, various growth factors or cytokines were pretreated to stem cells during in vitro cultivation to induce a specific direction of differentiation for transplanting in a damaged tissue [4]. For example, fibroblast growth factor 2 (FGF2) has been reported to enhance MSC proliferation $[5,6]$. The pretreated cells with 


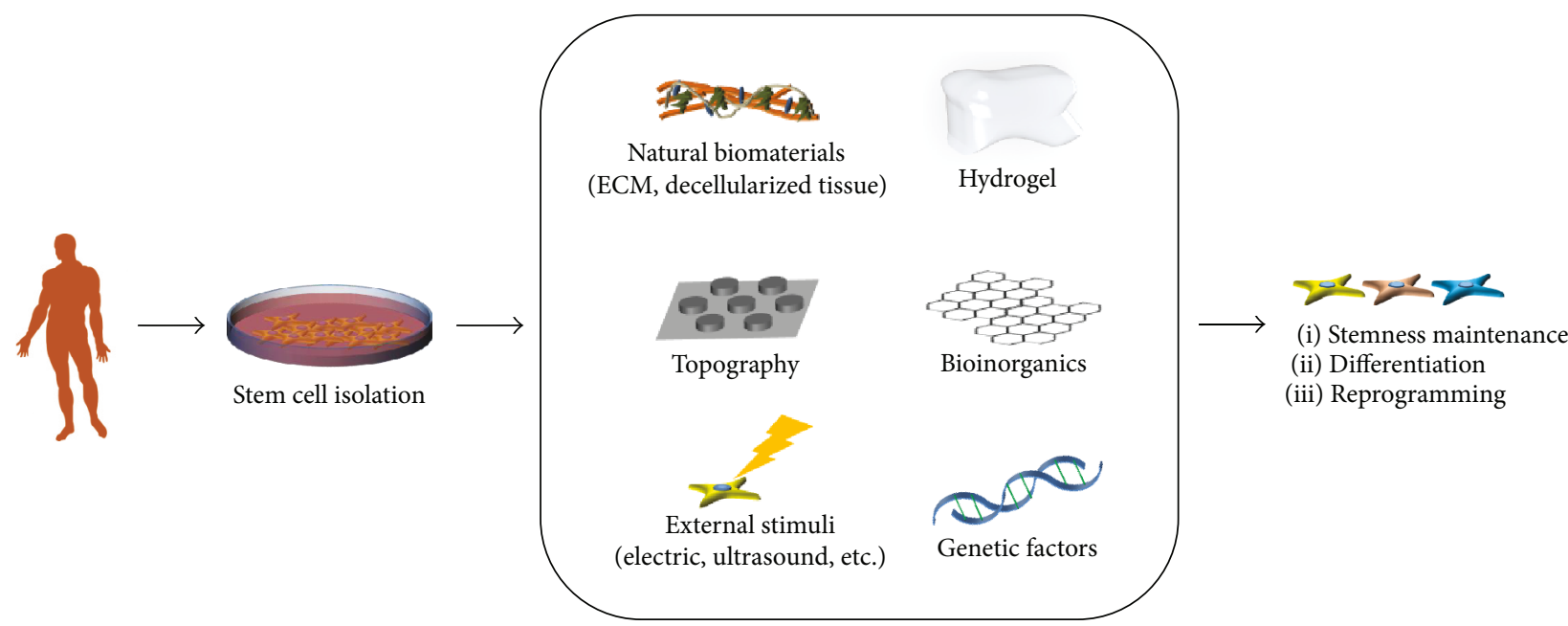

FIGURE 1: Strategies employing biomaterials and genetic factors to control stem cell fate. Stem cells can either maintain stemness, differentiate into specific lineages, or be reprogrammed to iPSCs.

growth factors, such as bone morphogenetic proteins (BMPs) or transforming growth factor $\beta$ (TGF- $\beta$ ), can promote MSCs to differentiate into osteoblast or chondrocyte in vitro and induce efficient bone formation and cartilage regeneration compared to no treatment control [7-10]. However, FGF2 treatment is not able to overcome cellular senescence and the loss of differentiation potential of MSCs [11]. Moreover, because of the short half-life of growth factors, a large amount of growth factors is required to achieve the goal, resulting in high cost. Also, direct injection of growth factors may cause serious side effects such as osteophyte formation, swelling, and synovial hyperplasia [9]. Because of such disadvantages of growth factor treatment, applying biomaterials (e.g., natural, synthetic), biophysical factors (e.g., ultrasound), or biochemical factors (e.g., gene transfection) have emerged as alternative encouraging strategies to control stem cell fate.

Here, we review the current strategies to control stem cell fate using biomaterials, physiochemical factors, and genetic factors (Figure 1) in the absence of growth factor treatment. We first reviewed the strategies for stemness maintenance of adult stem cells using physiochemical factors (Table 1) and biomaterials (Table 2). Next, we introduced various types of biomaterials which can help adult stem cells to induce differentiation into specific lineages (Table 3). Finally, we reviewed genetic reprogramming methods for induced pluripotent stem cells (iPSCs) (Tables 4 and 5).

\section{Improvement of MSC Stemness Using Biophysical Stimulation, Organic Compounds, and Biomaterials}

Adult stem cells, represented by MSCs, are considered as an attractive agent for cell therapy because of their ability to self-renew and differentiate into various tissue cell types $[12,13]$. However, the cell number when isolated is not usually sufficient for clinics. Therefore, a series of in vitro expansion of stem cell is indispensable. As MSCs lose their self-renewing ability and differentiation capacity during subculturing, maintenance of stemness has become an essential requirement for a successful stem cell therapy $[14,15]$. Here, we review biophysical stimulation (Table 1), organic compound treatment (Table 1), and biomaterials (Table 2) as major methodological factors to maintain mature and homogeneous differentiation of stem cells $[16,17]$.

2.1. Biophysical Stimulation. Biophysical stimuli are one of important factors to enhance the differentiation capability of MSCs, for example, when a normal human cartilage was continuously exposed to physical pressure, such as joint loading. This stimulus went through cell membranes, thereby playing a pivotal role in structural maturation of cartilage. As another example, when MSCs were subjected to lowintensity pulsed ultrasound (LIPUS) stimuli in vitro, the cells differentiated into chondrocytes. Furthermore, when chondrogenic differentiation was induced in alginate, LIPUSstimulated MSCs were not dedifferentiated even though the culture environment was not suitable for chondrogenic differentiation [18]. Along the same line, when MSCs were transplanted with PGA scaffold in a defect site post-LIPUS exposure for a week, the tissue morphology was maintained like an intact cartilage [19]. Another study demonstrated that when MSCs were stimulated with ultrasound, osteogenic differentiation was reduced compared to control MSCs $[20,21]$. This result suggests that biophysical stimulation has significant effects on MSCs to keep the undifferentiated or differentiated status.

2.2. Biochemical Stimulation. MSCs express important pluripotent factors including Oct4, Sox2, Nanog, and cMyc, and these factors have been widely studied. However, expression of these factors reduces when MSCs undergo cell senescence during a series of subculture [22-24]. To address this issue, overexpression of pluripotent factors through lentiviral transfection was studied, thereby enhancing the self-renewal and differentiation potential of MSCs [25]. In addition to pluripotent factors, the telomere activity was found to reduce 
TABLE 1: Maintenance of stemness using biophysical and biochemical stimulations.

\begin{tabular}{|c|c|c|c|c|}
\hline Type of stimulation & Details of condition & Type of cells & Observation & Ref. \\
\hline \multirow{4}{*}{$\begin{array}{l}\text { Biophysical } \\
\text { stimulation }\end{array}$} & $\begin{array}{l}\text { Low-intensity pulsed } \\
\text { ultrasound (LIPUS) }\end{array}$ & hMSCs & $\begin{array}{c}\text { hMSCs differentiated into chondrocyte without } \\
\text { dedifferentiation in nonchondrogenic differentiation } \\
\text { environments. }\end{array}$ & {$[18]$} \\
\hline & LIPUS & hMSCs & $\begin{array}{l}\text { The transplanted cells differentiated into chondrocytes } \\
\text { and regenerated defect sites of recipient cartilage. }\end{array}$ & [19] \\
\hline & Ultrasound & hMSCs & $\begin{array}{l}\text { Ultrasound treatment enhanced fracture healing by } \\
\text { promoting osteogenic differentiation of hMSCs. }\end{array}$ & {$[20]$} \\
\hline & Fluid flow & $\begin{array}{l}\text { Osteocyte, } \\
\text { osteoblast, } \\
\text { and hMSCs }\end{array}$ & $\begin{array}{l}\text { Flow stimulation promoted recruitment, proliferation, } \\
\text { and differentiation of osteoprogenitor cells. }\end{array}$ & {$[21]$} \\
\hline \multirow{3}{*}{$\begin{array}{l}\text { Overexpression } \\
\text { of genetical factor }\end{array}$} & SRY- (sex-determining & hMSCs & $\begin{array}{l}\text { Overexpression of Sox } 2 \text { enhanced stemness of MSCs } \\
\text { during in vitro cultivation. }\end{array}$ & [23] \\
\hline & Sirtuin 1 (SIRT1) & hMSC & $\begin{array}{l}\text { Overexpression of SirT1 prevented age-associated } \\
\text { senescence of MSCs via Sox } 2 \text { regulation. }\end{array}$ & {$[26,27]$} \\
\hline & $\begin{array}{l}\text { Octamer-binding } \\
\text { transcription factor } 4 \text { (Oct4) } \\
\text { or pron. nanOg (Nanog) }\end{array}$ & hMSC & $\begin{array}{l}\text { Viral transfection of Oct } 4 \text { or Nanog enhanced the } \\
\text { self-renewal and differentiation potential of MSCs. }\end{array}$ & {$[24,25]$} \\
\hline \multirow{2}{*}{$\begin{array}{l}\text { Treatment of } \\
\text { organic compound }\end{array}$} & Resveratrol & hMSCs & $\begin{array}{l}\text { Resveratrol treatment enhanced maintenance of the } \\
\text { self-renewal and differentiation capacity of MSCs } \\
\text { during ex vivo cultivation. }\end{array}$ & {$[28]$} \\
\hline & $\begin{array}{l}\text { Nuclear factor erythroid- } \\
\text { derived 2-like } 2 \text { (NRF2) }\end{array}$ & hMSCs & $\begin{array}{c}\text { Treatment of t-BHQ, the activator of NRF2, promoted } \\
\text { self-renewal ability and osteogenic differentiation } \\
\text { via inhibition of p53 expression. }\end{array}$ & {$[35]$} \\
\hline
\end{tabular}

during in vitro cultivation. Thus, sirtuin 1 (SIRT1: a class III histone deacetylase protein) was treated to induce expression of telomerase reverse transcriptase (TERT) [26]. Sirt1 is also known as an important factor which regulates the lifespan, aging, metabolic homeostasis, and age-associated senescence of MSCs by controlling Sox2 acetylation [27].

In order to develop a better strategy to reduce cell senescence or to improve stemness, organic compounds are treated to MSCs to prevent the decrease of pluripotent marker expression. For example, since resveratrol is an antioxidant as well as Sirt1 activator, its treatment improved the stability of Sox 2 by preventing acetylation and degradation of Sox 2 [27]. Moreover, sustained treatment of resveratrol during ex vivo expansion maintained self-renewal and differentiation capacities from an early passage until a late passage [28]. These results suggest that treating stem cells with antioxidants can be a reliable option to maintain MSC stemness during subculture.

Another major cause of cell senescence is intracellular accumulation of reactive oxygen species (ROS) [29] ("oxidative stress") which results in aging with end point apoptosis of MSCs [30, 31]. Nuclear factor (erythroid-derived 2)-like 2 (NRF2) plays a vital role in defending against oxidative stress at the cellular level. Therefore, conservation of NRF2 nuclear localization is important to overcome MSC aging during subculture $[32,33]$. A previous study reported that treatment of $\mathrm{t}-\mathrm{BHQ}$, an antioxidant, increased translocation of NRF2 into the nucleus and prevented cellular senescence by regulation of the p53-Sirt1 axis, as p53 can suppress the transcriptional activity of Sirt1 by binding to the Sirt1 promoter [34]. Due to such changes in cellular behaviors under
t-BHQ treatment, aged cells elevated the abilities for selfrenewal and osteogenic differentiation [35]. Together, the results suggest that antioxidant treatment is a promising approach to reduce cell senescence especially in long-term culture for a successful MSC therapy in vivo.

2.3. Biomaterials. The extracellular matrix (ECM) controls stem cell fate (e.g., proliferation and differentiation) through integrin-receptor binding $[36,37]$. Therefore, a series of biomaterials have been employed due to user-defined tunability of cell-matrix interaction (e.g., cell adhesion and cytoskeletal tension) as an artificial matrix platform. In this part, we introduce major types of biomaterials which have been used to maintain or to enhance stemness of adult stem cells, especially MSCs.

Biomaterials can be categorized into natural or synthetic materials in general. Among natural biomaterials, decellularized ECMs have been studied to control stem cell behavior recently. For example, the ECM where naive human MSCs (hMSCs) resided was decellularized and used for in vitro culture. This culture substrate was found to maintain stemness of human or mouse-derived adult stem cells most likely because it provided an in vivo-like stem cell niche [38-41]. Also, decellularized tendon tissue was found to maintain stemness and thereby promoted tenocyte differentiation of human tendon stem cells (hTSCs) by providing an amiable niche [42].

In addition to natural biomaterials, synthetic biomaterials have been recently designed to maintain or enhance stemness. For example, encapsulation of MSCs into hydrogels can mimic the three-dimensional microenvironment of 
TABLE 2: Maintenance of stemness using biomaterials.

\begin{tabular}{|c|c|c|c|c|}
\hline Type of biomaterials & Details of materials & Type of cells & Observation & Ref. \\
\hline \multirow{2}{*}{$\begin{array}{l}\text { Natural } \\
\text { (nonsynthetic) }\end{array}$} & $\begin{array}{l}\text { Decellularized ECM of } \\
\text { undifferentiated hMSCs }\end{array}$ & $\begin{array}{l}\text { hMSCs } \\
\text { mASCs }\end{array}$ & $\begin{array}{c}\text { Decellularized ECM of undifferentiated MSCs promoted } \\
\text { self-renewal, colony formation, and stemness maintenance } \\
\text { of hMSCs. }\end{array}$ & {$[38-41]$} \\
\hline & $\begin{array}{l}\text { Decellularized } \\
\text { tendon tissue }\end{array}$ & hTSCs & $\begin{array}{l}\text { Decellularized tendon tissues enhanced self-renewal and } \\
\text { stemness maintenance of hTSCs. }\end{array}$ & {$[42]$} \\
\hline \multirow{4}{*}{ Hydrogel } & $\begin{array}{l}\text { Polyacrylamide gels } \\
\text { and PDMS stamps }\end{array}$ & hMSCs & $\begin{array}{l}\text { Low cytoskeletal tension was maintained by controlling } \\
\text { substrate stiffness as cell spreading was restricted, thereby } \\
\text { enhancing stemness. Polyacrylamide gels and PDMS stamps } \\
\text { were used to regulate biophysical parameters. }\end{array}$ & [43] \\
\hline & $\begin{array}{l}\text { Alginate/GelMA } \\
\text { hydrogels }\end{array}$ & $\begin{array}{l}\text { hBMSCs } \\
\text { and } \\
\text { GMSCs }\end{array}$ & $\begin{array}{l}\text { Compared to alginate hydrogels, alginate/GelMA hydrogels } \\
\text { maintained stemness due to decreased hydrogel stiffness. }\end{array}$ & {$[44]$} \\
\hline & $\begin{array}{l}\text { Pullulan-collagen } \\
\text { hydrogel }\end{array}$ & mBMSCs & $\begin{array}{l}\text { Biomimetic hydrogel maintained stemness of mouse bone } \\
\text { marrow-derived MSCs (mBMSCs) compared to tissue plate } \\
\text { culture, resulting in enhanced viability after in vivo injection. }\end{array}$ & [45] \\
\hline & $\begin{array}{l}\text { RGD-modified } \\
\text { poly(carboxybetaine) } \\
\text { hydrogel }\end{array}$ & hBMSCs & $\begin{array}{l}\text { hMSCs formed 3D spheroids on the } 5 \mu \mathrm{M} \text { RGD substrate, } \\
\text { and the stemness was well maintained compared to } 5 \mathrm{mM} \\
\text { RGD substrate, which enhanced osteogenic differentiation. }\end{array}$ & [46] \\
\hline \multirow{2}{*}{ Topography } & PCL & hMSCs & $\begin{array}{l}\text { A surface nanopattern with } 120 \mathrm{~nm} \text { pits in a square arrangement } \\
\text { with a center-center spacing of } 300 \mathrm{~nm} \text { enhanced stemness of } \\
\text { hMSCs compared to the flat PCL surface. }\end{array}$ & [47] \\
\hline & PDMS & hBMSCs & $\begin{array}{l}\text { A PDMS nanopattern } 250 \mathrm{~nm} \text { in depth, } 350 \mathrm{~nm} \text { in width, and } \\
\text { with } 700 \mathrm{~nm} \text { pitch decreased hBMSC stemness compared to } \\
\text { the flat surface control. }\end{array}$ & [48] \\
\hline \multirow{4}{*}{$\begin{array}{l}\text { Polymeric } \\
\text { surface } \\
\text { coating }\end{array}$} & \multirow{2}{*}{ PLL-coated surface } & hBMSCs & $\begin{array}{l}\text { PLL-coated surface improved proliferation but retarded the } \\
\text { replicative senescence of hBMSCs by increasing the S-phase. }\end{array}$ & [49] \\
\hline & & hHSCs & $\begin{array}{l}\text { PLL substrates increased the total number of hHSCs while } \\
\text { stemness was maintained. }\end{array}$ & [50] \\
\hline & PCL nanofiber & hMSCs & $\begin{array}{l}\text { Bone marrow collagen-mimetic PCL nanofiber matrices } \\
\text { increased the expression of self-renewal factors and cell-cell } \\
\text { interaction markers in hMSCs. }\end{array}$ & {$[51]$} \\
\hline & PEG-PCL copolymer & hMSCs & $\begin{array}{l}\text { PEG-PCL copolymer exhibited moderate surface repellency } \\
\text { and induced aggregation of hMSCs, which promoted stemness } \\
\text { and lowered intracellular ROS accumulation. }\end{array}$ & {$[52]$} \\
\hline \multirow{2}{*}{$\begin{array}{l}\text { Nanofibrous } \\
\text { scaffold }\end{array}$} & $\begin{array}{l}\text { Emu oil-loaded } \\
\text { PCL/Coll nanofiber }\end{array}$ & hASCs & $\begin{array}{l}\text { Emu oil-loaded nanofibers with higher tensile strength } \\
\text { enhanced the expression of stemness, proliferation, and cell } \\
\text { adhesion markers in hASCs compared to unloaded nanofibers. }\end{array}$ & [53] \\
\hline & Gelatin nanofiber & hMSCs & $\begin{array}{l}\text { 3D culture of hMSC in a nanostructured electrospun gelatin } \\
\text { patch maintained stemness of hMSCs for } 3 \text { weeks. }\end{array}$ & [54] \\
\hline \multirow{2}{*}{ Chitosan } & Chitosan film & hASC & $\begin{array}{l}\text { The chitosan film induced spheroid formation of hASCs with } \\
\text { higher activities of self-renewal and colony formation, as well } \\
\text { as significant upregulation of pluripotency marker expression. }\end{array}$ & [56] \\
\hline & Chitosan film + hypoxia & hUCBMSC & $\begin{array}{c}\text { The chitosan film promoted spheroid formation of hUCBMSC } \\
\text { under hypoxia than normoxia. HIF-1 additionally induced } \\
\text { expression of stemness genes. }\end{array}$ & [57] \\
\hline
\end{tabular}

native tissues. Polyacrylamide, alginate/GelMA, or pullulancollagen hydrogels with low stiffness maintained stemness because they helped with the maintenance of low cytoskeletal tension [43-45]. Also, decreasing the cell matrixbinding affinity by reducing the Arg-Gly-Asp (RGD) density is revealed to enhance stemness in poly(carboxybetaine) hydrogels [46].

Besides, surface topography is a common method to control cell behavior related to stemness. While MSCs were cultured on nanopatterned poly( $\varepsilon$-caprolactone) (PCL) substrates with $120 \mathrm{~nm}$ pits in a square arrangement with a centre-centre spacing of $300 \mathrm{~nm}$, stemness was enhanced [47]. On the other hand, nanotopography with an aligned shape (polydimethylsiloxane, $250 \mathrm{~nm}$ in depth, $350 \mathrm{~nm}$ in width, and with $700 \mathrm{~nm}$ pitch) did not enhance MSC stemness compared to a nontopographic surface [48].

Polymeric surface coating serves as another promising option to control stemness. Poly-L-lysine (PLL) is a widely 
TABLE 3: Direct differentiation using biomaterials.

\begin{tabular}{|c|c|c|c|c|c|}
\hline Property & $\begin{array}{l}\text { Type of } \\
\text { materials }\end{array}$ & Differentiation & Details of materials & Comments & Ref. \\
\hline \multirow{8}{*}{ Composition } & \multirow{4}{*}{ Scaffold } & Chondrogenesis & Cellulose/silk blend & $\begin{array}{l}\text { Growing MSCs on a specific blend } \\
\text { combination of cellulose and silk in a } \\
75: 25 \text { ratio significantly upregulated } \\
\text { expression of chondrogenic markers. }\end{array}$ & {$[120]$} \\
\hline & & myogenesis & $\begin{array}{l}\text { ECM-like porous scaffold of } \\
\text { poly(3-hydroxybutyric acid-co-3- } \\
\text { hydroxyvaleric acid) (PHBHV)/ } \\
\text { gelatin blends }\end{array}$ & $\begin{array}{l}\text { PHBHV/gelatin constructs mimicking } \\
\text { myocardial structural properties. }\end{array}$ & [121] \\
\hline & & $\begin{array}{l}\text { Chondrogenesis/ } \\
\text { osteogenesis }\end{array}$ & Collagen-glycosaminoglycan & $\begin{array}{l}\text { Collagen-chondroitin sulphate (CCS) } \\
\text { scaffolds enhanced osteogenesis while } \\
\text { collagen-hyaluronic acid (CHyA) } \\
\text { scaffolds enhanced chondrogenesis. }\end{array}$ & [122] \\
\hline & & Cardiomyogenesis & $\begin{array}{l}\text { Carbon nanotube/poly-L- } \\
\text { lactide acid (PLA) nanofiber }\end{array}$ & $\begin{array}{l}\text { The two-pronged carbon nanotube } \\
\text { template provided a biomimetic } \\
\text { electroactive cue, thereby directing } \\
\text { MSC differentiation. }\end{array}$ & {$[13]$} \\
\hline & \multirow{2}{*}{$\begin{array}{l}\text { Decellularized } \\
\text { tissues }\end{array}$} & Chondrogenesis & $\begin{array}{l}\text { Cartilage extracellular matrix- } \\
\text { derived particles (CEDPs) }\end{array}$ & $\begin{array}{l}\text { Microtissue aggregates (BMSCs and } \\
\text { CEDPs }(263 \pm 48 \mu \mathrm{m} \text { ) cocultured in a } \\
\text { rotary cell culture system) showed a } \\
\text { more rapid restoration of joint } \\
\text { functions with superior cartilage repair } \\
\text { compared to the control groups in vivo. }\end{array}$ & [3] \\
\hline & & Osteogenesis & $\begin{array}{l}\text { Calcium phosphate nanoparticles } \\
\text { and demineralized bone matrix } \\
\text { (DBM) particles incorporated } \\
\text { into injectable polyHIPE }\end{array}$ & $\begin{array}{l}\text { PolyHIPE compositions with BMSCs } \\
\text { promoted osteogenic differentiation } \\
\text { through upregulation of bone-specific } \\
\text { marker expression compared to a time } \\
\text { zero control. }\end{array}$ & [4] \\
\hline & Bioinorganics & Osteogenesis & 3D graphene foams (GFs) & $\begin{array}{l}\text { 3D GF culture platforms maintained } \\
\text { stem cell viability and promoted } \\
\text { osteogenic differentiation. }\end{array}$ & [123] \\
\hline & Biomimetics & Chondrogenesis & $\begin{array}{l}\text { Polyacrylate substrate functionalized } \\
\text { with RGD peptide }\end{array}$ & $\begin{array}{l}\text { Biomimetic polyacrylate substrates } \\
\text { can direct chondrogenic differentiation } \\
\text { of mMSCs, hMSCs, and mouse KSCs } \\
\text { in the absence of exogenous TGF-bs. }\end{array}$ & [124] \\
\hline \multirow{3}{*}{$\begin{array}{l}\text { Substrate } \\
\text { stiffness }\end{array}$} & \multirow{3}{*}{ Hydrogels } & $\begin{array}{l}\text { Osteogenesis/ } \\
\text { neurogenesis }\end{array}$ & $\begin{array}{l}\text { Polyacrylamide }(0.5 \sim 40 \mathrm{kPa}) \\
\text { hydrogel substrate }\end{array}$ & $\begin{array}{l}\text { MSCs on soft }(\sim 0.5 \mathrm{kPa}) \text { gels promoted } \\
\text { expression of neurogenesis markers while } \\
\text { MSCs on stiff }(\sim 40 \mathrm{kPa}) \text { substrates } \\
\text { elevated expression of osteogenesis } \\
\text { markers. Transfer of MSCs from soft } \\
\text { to stiff or stiff to soft substrates led to a } \\
\text { switch in the lineage specification. }\end{array}$ & {$[60]$} \\
\hline & & $\begin{array}{l}\text { Osteogenesis/ } \\
\text { chondrogenesis }\end{array}$ & $\begin{array}{l}\text { Methyl acrylate/methyl } \\
\text { methacrylate }(18-72 \mathrm{MPa}) \\
\text { hydrogel substrate }\end{array}$ & $\begin{array}{l}\text { Both chondrogenic and osteogenic } \\
\text { markers were elevated when MSCs } \\
\text { were grown on substrates with } \\
\text { stiffness }<10 \mathrm{MPa} \text {. } \\
\text { MSCs on lower stiffness gels express } \\
\text { elevated chondrogenesis markers while } \\
\text { MSCs on the higher stiff substrates } \\
\text { express elevated osteogenesis markers. }\end{array}$ & {$[61]$} \\
\hline & & Angiogenesis & $\begin{array}{l}\text { Gelatin hydrogel conjugating } \\
\text { enzymatically cross linkable } \\
\text { hydroxyphenyl propionic acid } \\
\text { (GHPA) }\end{array}$ & $\begin{array}{l}\text { GHPA as a promising soluble factor-free } \\
\text { cell delivery template induced endothelial } \\
\text { differentiation of MSCs with robust } \\
\text { neovasculature formation with favorable } \\
\text { host responses. }\end{array}$ & {$[63]$} \\
\hline
\end{tabular}


TABLE 3: Continued.

\begin{tabular}{|c|c|c|c|c|c|}
\hline Property & $\begin{array}{c}\text { Type of } \\
\text { materials }\end{array}$ & Differentiation & Details of materials & Comments & Ref. \\
\hline & & Angiogenesis & PEGylated fibrin 3D matrix & $\begin{array}{c}\text { Endothelial differentiation of MSC } \\
\text { was induced by the 3D PEGylated } \\
\text { fibrin matrix. }\end{array}$ & {$[64]$} \\
\hline \multirow{5}{*}{$\begin{array}{l}\text { Surface } \\
\text { topograpy }\end{array}$} & Film & $\begin{array}{l}\text { Neurogenesis/ } \\
\text { myogenesis }\end{array}$ & $\begin{array}{l}\text { Micropatterned poly(lactic-co- } \\
\text { glycolic acid) (PLGA) ultrathin film }\end{array}$ & $\begin{array}{l}\text { Micropattering: microsize lanes of } 20 \mu \mathrm{m} \\
\text { width separated by } 40 \mu \mathrm{m} \text { wide grooves } \\
\text { on a PLGA ultrathin film }(16.3 \pm 1.5 \mu \mathrm{m})\end{array}$ & {$[66]$} \\
\hline & Hydrogel & $\begin{array}{c}\text { Adipogenesis/ } \\
\text { neurogenesis }\end{array}$ & $\begin{array}{c}\text { Hydrazine-treated polyacrylamide } \\
\text { gel (circular and anisotropic } \\
\text { geometry) }\end{array}$ & $\begin{array}{l}\text { Cells cultured in small circular islands } \\
\text { show elevated expression of adipogenesis } \\
\text { markers while cells that spread in } \\
\text { anisotropic geometries elevated } \\
\text { expression of neurogenic markers. }\end{array}$ & {$[67]$} \\
\hline & \multirow{3}{*}{ Bioinorganics } & $\begin{array}{l}\text { Osteogenesis/ } \\
\text { neurogenesis }\end{array}$ & Graphene/electrical stimulation & $\begin{array}{l}\text { Specific combinations of nonbiological } \\
\text { inputs-material type, electrical } \\
\text { stimulation, and physical patterns on } \\
\text { graphene substrates regulated hMSC } \\
\text { lineage specification. }\end{array}$ & {$[70]$} \\
\hline & & Osteogenesis & $\begin{array}{c}\text { Nanotubule-shaped titanium } \\
\text { oxide surface }\end{array}$ & $\begin{array}{l}\text { Small ( } 30 \mathrm{~nm} \text { diameter) nanotubes } \\
\text { promoted cell adhesion without } \\
\text { noticeable differentiation, whereas larger } \\
\text { ( } 70 \text { to } 100 \mathrm{~nm} \text { diameter) nanotubes } \\
\text { elicited a dramatic stem cell elongation } \\
\text { (10-fold increased), which induced } \\
\text { cytoskeletal stress and selective } \\
\text { differentiation into osteoblast-like cells. }\end{array}$ & {$[71]$} \\
\hline & & Osteogenesis & Titanium substrate & $\begin{array}{c}\text { Surface microstructure and surface } \\
\text { energy from microstructured } \mathrm{Ti} \\
\text { substrate were able to direct osteogenic } \\
\text { differentiation of mesenchymal stem cells. }\end{array}$ & {$[72]$} \\
\hline
\end{tabular}

used polymer as a surface coating material, because it improves proliferation but retards replicative senescence by increasing the S-phase population of MSCs [49] and hematopoietic stem cells (HSCs) [50] in the cell cycle. Also, coating the culture substrate with PCL nanofibers which can mimic the size and shape of collagen fibers of ECM is also known to maintain stemness [51]. As another approach, poly(ethylene glycol)-poly( $\varepsilon$-caprolactone) (PEG-PCL) copolymers were used to control surface repellency by altering the molar percentage or chain length of PEG. This surface repellency induced aggregation of hMSCs by upregulation of cell-cell interaction proteins such as connexin-43, which further increased stemness with a significant decrease in intracellular ROS accumulation (Figure 2) [52].

Furthermore, nanofibrous scaffolds provided a $3 \mathrm{D}$ microenvironment to stem cells and thus enhanced stemness. For example, ASCs displayed an improved adhesion capacity with high rates of bioactivity and proliferation when cultured on emu oil-loaded nanofibers [53]. Mesenchymal stem cells (MSCs) showed a superior differentiation capacity towards typical mesenchymal lineages when grown in a nanostructured electrospun gelatin patch [54]. Especially, emu oil exhibited a free radical scavenging activity, thereby enhancing stemness [55].

Finally, a chitosan film induced spheroid formation and triggered a cell-cell interaction of hASCs, thereby enhancing stemness. After spheroid formation, the spheroid-forming hASCs expanded efficiently, formed a colony, and upregulated the expression of pluripotency marker genes compared to the monolayer-cultured control condition $[56,57]$.

In conclusion, the aforementioned types and formats of biomaterials were found to enhance or maintain stemness. We summarize the three major mechanisms by which the biomaterials enhanced or maintained stemness as follows: (1) reduction of cytoskeletal tension by reducing matrix stiffness, (2) spheroid formation by reduction of integrin-binding sites and consequent promotion of cell-cell interaction, and (3) antioxidative effects by radical scavenging activity. These strategies have potential to effectively improve stemness of MSCs in various biomaterial formats.

\section{Direct Differentiation of MSCs Using Biomaterials}

While most methods known to induce mesenchymal lineage differentiation of MSC depend on exposure to one or more soluble growth factors, a growing body of evidence suggests that it is possible to control MSC differentiation in the absence of soluble factors. MSCs exhibit the ability to differentiate towards specific lineages through biomaterials with modification of mechanical or biochemical properties, matrix composition, topography, and surface stiffness. This 
TABLE 4: iPSC reprogramming and type of gene transfection.

\begin{tabular}{|c|c|c|c|c|c|}
\hline Type & Advantages & Disadvantages & $\begin{array}{l}\text { Transgene } \\
\text { expression }\end{array}$ & Efficiency & Ref. \\
\hline \multicolumn{6}{|l|}{ Virus } \\
\hline Adenovirus & $\begin{array}{l}\text { Nonintegrative; infects } \\
\text { dividing and nondividing cells }\end{array}$ & Low efficiency & No & $0.0001 \sim 0.01 \%$ & {$[84,85]$} \\
\hline Lenti/retrovirus & $\begin{array}{l}\text { Ease of handling with } \\
\text { experience; medium-high } \\
\text { efficacy }\end{array}$ & $\begin{array}{c}\text { Integration of foreign DNA } \\
\text { into genome; residual expression } \\
\text { of reprogramming factors; } \\
\text { controversy regarding tumor } \\
\text { formation }\end{array}$ & Yes & $0.1 \sim 1 \%$ & {$[73,125]$} \\
\hline Sendai virus & $\begin{array}{l}\text { Medium-high efficiency; } \\
\text { nonintegrating; robust } \\
\text { protein-expressing property; } \\
\text { wide host range }\end{array}$ & Involve viral transduction & No & $0.5 \sim 1.0 \%$ & {$[88,89]$} \\
\hline \multicolumn{6}{|l|}{ Plasmid vector } \\
\hline Episomal & $\begin{array}{l}\text { Nonintegrative; simple to } \\
\text { implement to laboratory } \\
\text { setup; less time-consuming }\end{array}$ & $\begin{array}{l}\text { Very low efficiency; the use } \\
\text { of potent viral oncoprotein } \\
\text { (SV40LT antigen) }\end{array}$ & No & $3-6 \times 10-6$ & {$[87,126]$} \\
\hline Minicircle & $\begin{array}{l}\text { More persistent transgene } \\
\text { expression; lack bacterial origin }\end{array}$ & Very low efficiency & No & $0.01 \%$ & {$[127]$} \\
\hline miRNA & $\begin{array}{l}\text { Relative high efficiency; } \\
\text { nonintegration; easily } \\
\text { automated, making it an } \\
\text { exciting candidate for } \\
\text { routine biomanufacture. }\end{array}$ & $\begin{array}{c}\text { Requires high gene dosages } \\
\text { and multiple transfections; } \\
\text { daily transfection; controversy } \\
\text { in reproducibility and mitigating } \\
\text { cost effectiveness }\end{array}$ & No & $1.4 \sim 2 \%$ & {$[128,129]$} \\
\hline $\begin{array}{l}\text { PiggyBac } \\
\text { transposons }\end{array}$ & $\begin{array}{c}\text { Elimination of insertional } \\
\text { mutagenesis; no footprint } \\
\text { upon excision; higher genome } \\
\text { integration efficiency }\end{array}$ & $\begin{array}{l}\text { Inefficient excision, potential } \\
\text { for genomic toxicity }\end{array}$ & $\begin{array}{l}\text { Excision with } \\
\text { transposase }\end{array}$ & $0.1 \sim 1 \%$ & {$[80]$} \\
\hline Protein & $\begin{array}{l}\text { Free of genetic materials; } \\
\text { direct delivery of reprogramming } \\
\text { factor proteins }\end{array}$ & $\begin{array}{c}\text { Slow kinetics, low efficiency; } \\
\text { difficulties in generation and } \\
\text { purification of reprogramming } \\
\text { protein }\end{array}$ & No & $0.005 \sim 0.001 \%$ & {$[130]$} \\
\hline Small molecules & $\begin{array}{l}\text { Ease of handling; no requirements } \\
\text { for reprogramming factors }\end{array}$ & More than one target, toxicity & No & $0.3 \sim 0.5 \%$ & {$[86]$} \\
\hline
\end{tabular}

TABLE 5: iPSC reprogramming and donor cell type.

\begin{tabular}{lc}
\hline Donor cell type & Ref. \\
\hline Adipose-derived stem cells & {$[131]$} \\
Amniotic fluid & {$[132]$} \\
Blood cell cord blood stem cells & {$[104]$} \\
B lymphocytes & {$[133]$} \\
Bone marrow cells & {$[134]$} \\
Cardiac myocytes & {$[135]$} \\
Dental pulp & {$[136]$} \\
Dermal fibroblasts & {$[137]$} \\
Endometrial stromal fibroblasts & {$[100]$} \\
Hematopoietic progenitor cells & {$[138]$} \\
Hepatocytes & {$[139]$} \\
Keratinocytes (from hair pluck) & {$[101]$} \\
Pancreatic $\beta$-cells & {$[140]$} \\
Peripheral blood mononuclear cell & {$[126]$} \\
\hline
\end{tabular}

approach would simplify the tissue engineering procedure and be cost-effective. Here, we summarize recent studies that employed such approaches to induce direct differentiation of MSC via biomaterial technologies (Table 3).

3.1. Composition. Collagen and glycosaminoglycan (GAG), major components of natural ECM, play a key role in osteochondral regeneration. Hence, their combined (CG) scaffolds have been used successfully in tissue engineering applications for regeneration of cartilage and bone $[57,58]$. A previous study reported the effect of the composition and stiffness of collagen and GAG scaffolds composed of chondroitin sulphate (CS) and hyaluronic acid (HA) on MSC differentiation [59]. The study showed that the lowest stiffness $(0.5 \mathrm{kPa})$ of the CG scaffold facilitated chondrogenesis, while the stiffest $(1.5 \mathrm{kPa})$ scaffold induced osteogenesis. This was the first evidence proving that osteochondral differentiation of MSC could be directed via scaffold composition using CG and further enhanced by the GAG type. When cellulose, another abundant natural polymer, was blended with silk at different compositions, growth and chondrogenesis of MSC were 


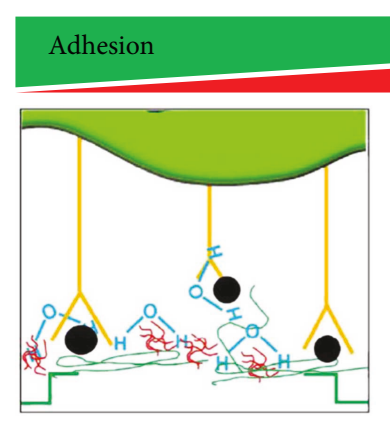

Stemness
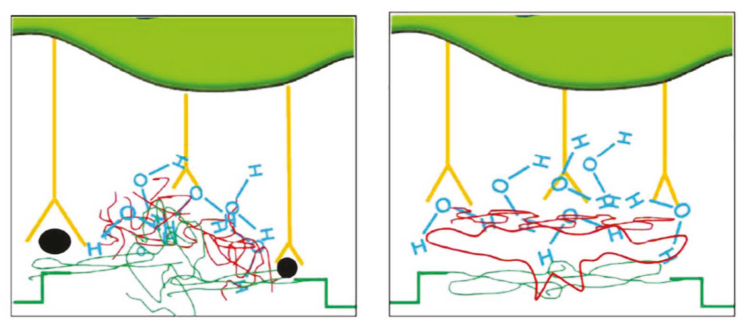

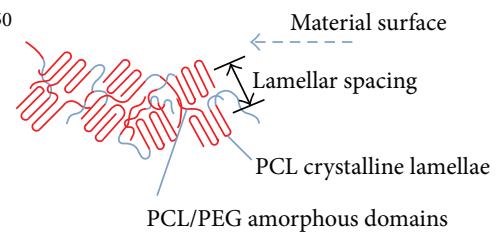

$\mathrm{PEG}_{2 \mathrm{k}}$ or $\mathrm{PEG}_{5 \mathrm{k}}$

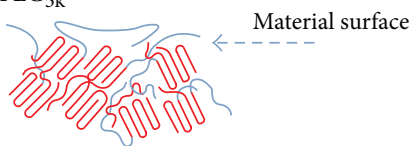

PCL
PEG

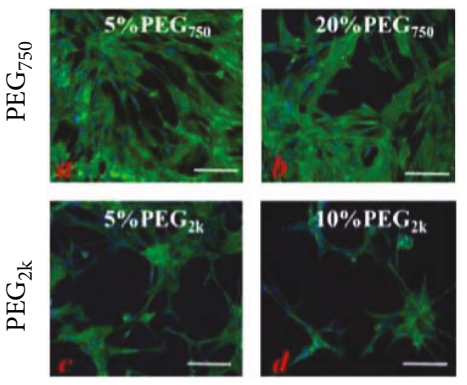

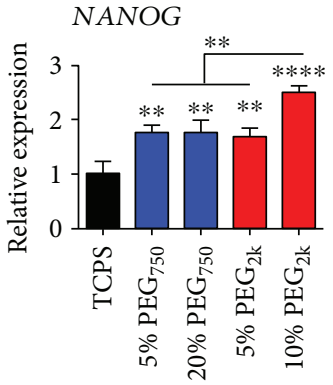

(c)

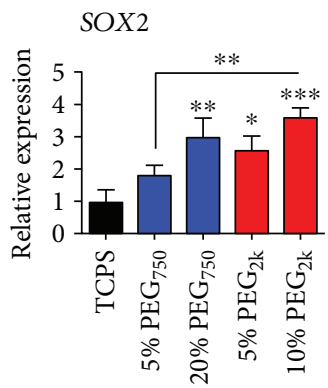

(d)

Redox regulation

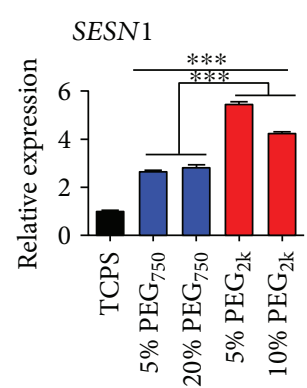

(e)

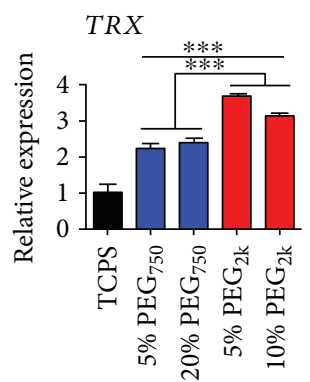

(f)

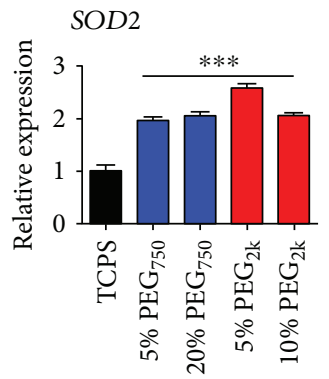

(g)

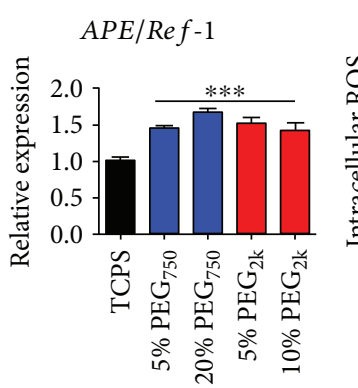

(h)

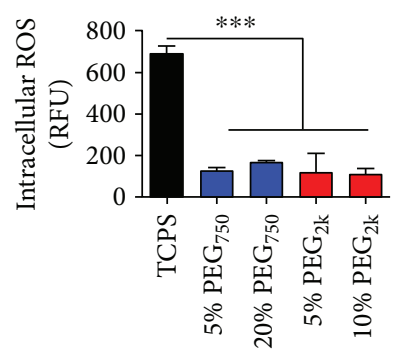

(i)

FIGURE 2: PEG chain length-dependent interactions with the PCL matrix enable stemness maintenance. Proper control of surface repellency by copolymerizing $\mathrm{PEG}_{2 \mathrm{k}}$ with PCL in a culture substrate form can improve stemness as cell-cell interaction increases relatively to cell-matrix interaction, thereby forming pseudo cell spheroids. Figure 2 is reproduced with permission from [52], American Chemical Society. All bars are mean \pm S.D. ${ }^{*} p<0.05,{ }^{* *} p<0.01,{ }^{* * *} p<0.001,{ }^{* * * *} p<0.0001$ relative to TCPS or as indicated between the lines.

promoted [60]. This was also the first report demonstrating the potential of cellulose to induce chondrogenic differentiation of MSC.

Recent studies investigated whether chondrogenic differentiation of MSC could be directed by biomimetic or decellularized tissue-derived materials. Biomimetic polyacrylate substrates functionalized with the RGD integrin-binding peptide promoted chondrogenesis of MSC in the absence of any soluble growth factors [61]. They suggested that the amount of surface amine residues from the RGD peptide was a key regulator to inducing the differentiation. Several studies demonstrated that ECM components derived from the cartilage promoted chondrogenesis of MSC [62-64]. In all cases, however, the use of chondrogenic growth factors was found to be essential for MSC chondrogenesis with deposition of necessary matrix components. In addition, a study reported that novel particles derived from natural cartilage ECM induced chondrogenic differentiation of MSC even in the absence of TGF- $\beta$ when the particles were used as a cell carrier [65].

Calcium phosphate- (CaP-) based ceramics play a significant role in bone repair due to their osteoconductive 

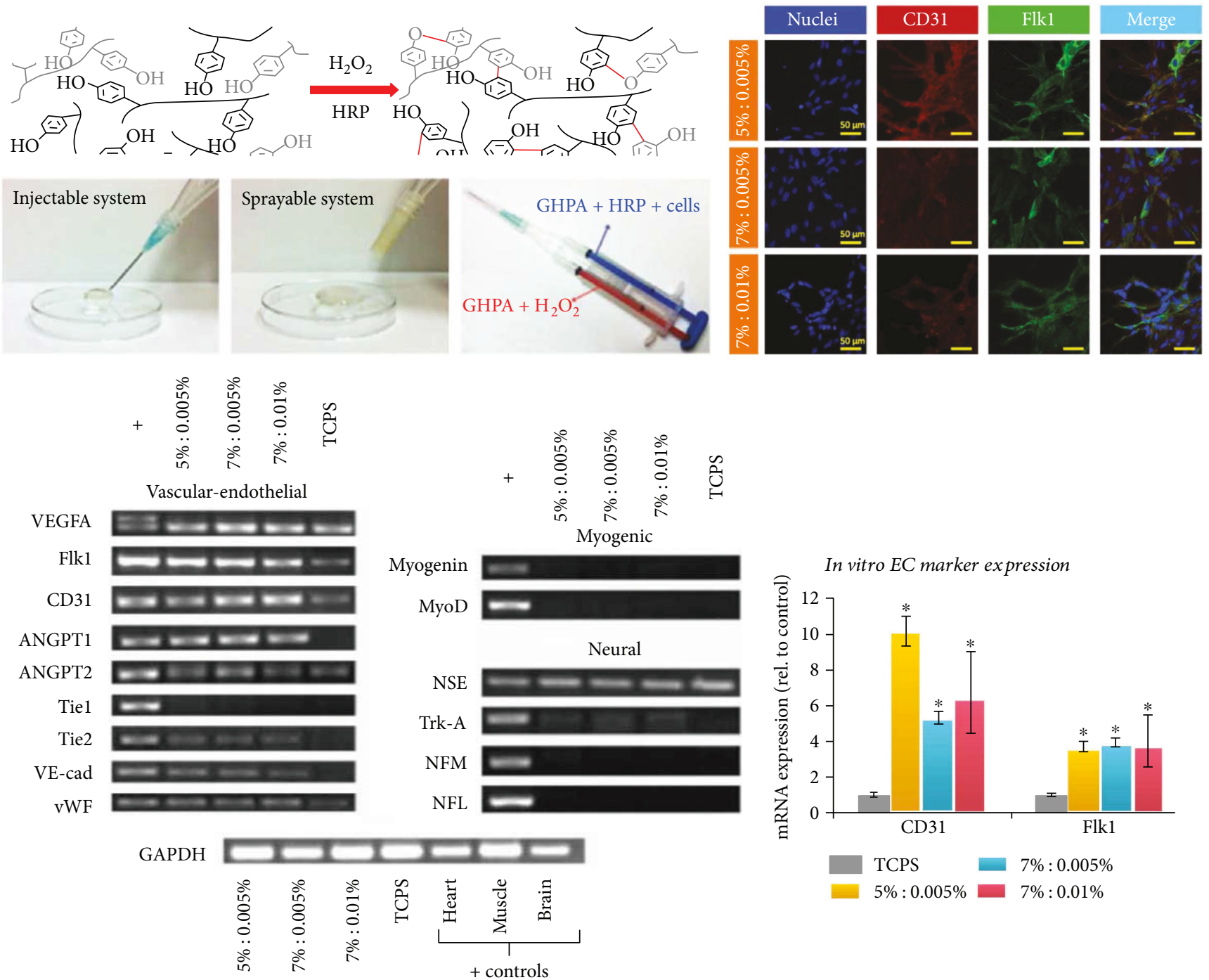

Figure 3: Gelation of GHPA by $\mathrm{H}_{2} \mathrm{O}_{2}$ and horseradish peroxidase-catalyzed cross linking. In vitro endothelial differentiation of hMSCs in GHPA hydrogels. Figure 3 is reproduced with permission from [63], John Wiley and Sons. ${ }^{*}$ indicates $p<0.05$ in comparison to the control MSCs on tissue culture plate.

potential for filling lost bone volumes, when CaP nanoparticles and demineralized bone matrix (DBM) were fabricated as an injectable bone graft by incorporating polymerized high internal phase emulsions (polyHIPEs). This injectable bone graft was found to induce direct osteogenesis of MSC [58]. On the other hand, our recent study investigated the potential of $3 \mathrm{D}$ graphene substrates to induce spontaneous osteogenesis of MSC without additional stimuli [59]. These reports revealed that material-derived cues were able to guide MSC differentiation to osteogenesis in the absence of extrinsic biochemical inputs.

Proper regeneration of the myocardium is dependent on scaffold properties and thus can be enhanced by mimicking features of the myocardial ECM. A three-hydroxybutyrate and 3-hydroxyvalerate (PHBHV)/gelatin construct mimicking the myocardial ECM structure was developed to promote cardiac differentiation of MSC and cardiac resident cells without any chemical stimulation [66]. This study demonstrated that when specific physicochemical properties with a microtopograph were produced to mimic the structural and mechanical properties of myocardium in the PHBHV/ gelatin construct, myogenesis of the stem cells was promoted. Electroconductive carbon nanotubes (CNT) demonstrated an ability to induce myogenic differentiation of MSC in the absence of additional stimuli [67]. Although the exact mechanism of this result is unclear, it was suggested that electrical stimulation of MSC by culturing on the CNT-based polylactic acid scaffold was a key factor to enhancing differentiation to cardiomyocytes.

3.2. Substrate Stiffness. Among the biophysical cues that were identified to regulate cell fate in static in vitro cultures, stiffness of culture substrates was suggested first as a key property in several important studies [60-64]. An increased stiffness of the culture substrate was found to induce osteogenic differentiation of MSCs $[60,61]$. The role of matrix stiffness in directing lineage specification of MSCs was examined on the surface-charged methyl acrylate/methyl methacrylate 

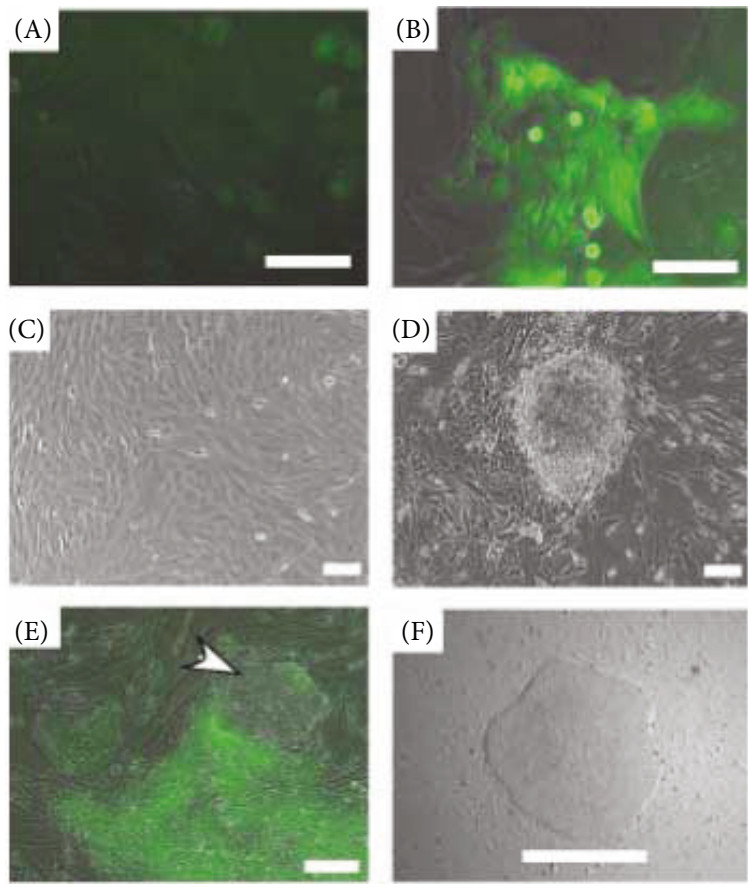

(a)
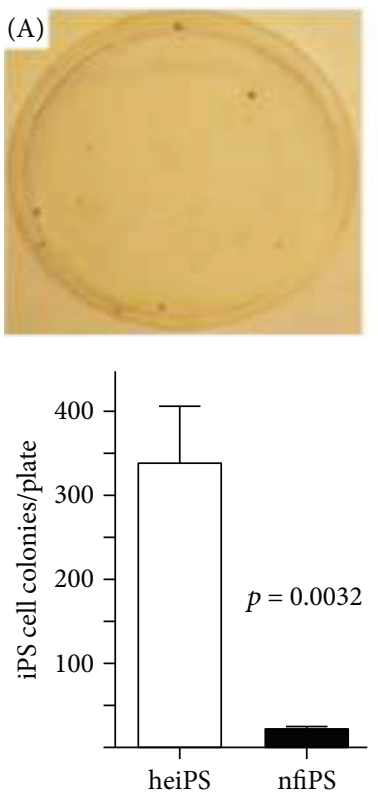

(C)
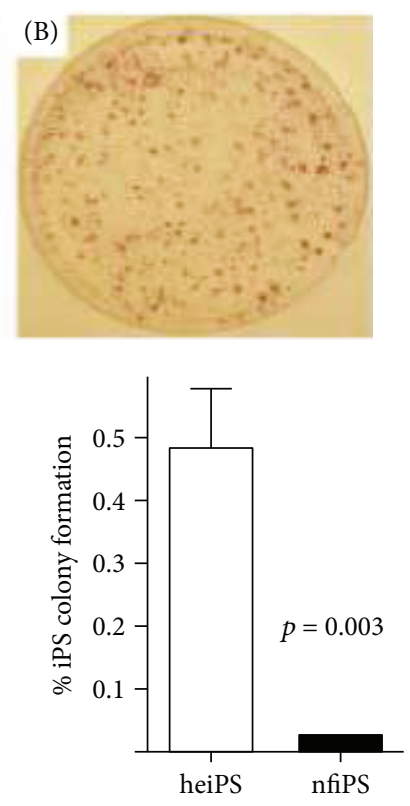

(D)

(b)
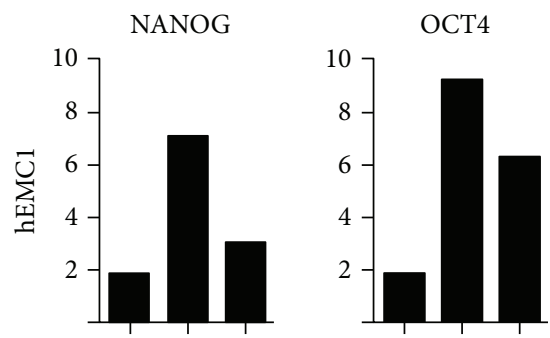
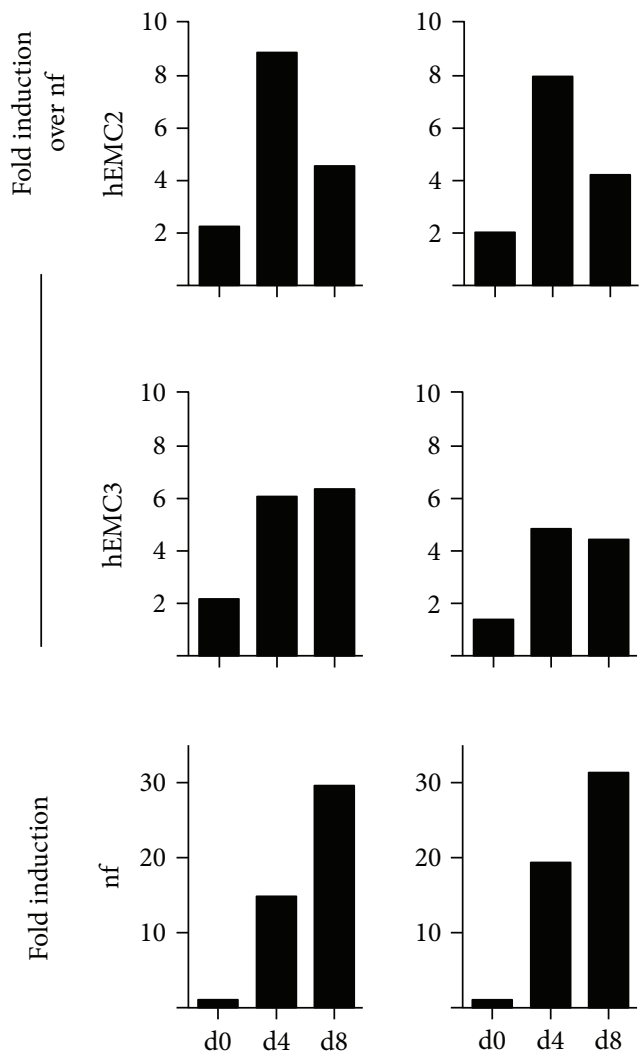

(c)

FIGURE 4: Pluripotency reprogramming of human endometrial cells (hEMC). hEMC-derived iPS (heiPS) showed higher expression of pluripotent markers compared to neonatal fibroblasts. Figure 4 is reproduced with permission from [100], Oxford University Press.

(MA/MMA) polymer substrate with varying elastic modulus [60]. This study demonstrated that the substrate group with lower stiffness induced chondrogenesis of MSCs while the substrate with rigid stiffness induced osteogenic specification of MSCs. Although its specific mechanism is unclear, this study revealed that integrin $\beta 1$ played a critical role in this process. Cells sense their mechanical microenvironment via integrin-ligand interactions which form focal adhesions and thereby regulate intracellular signaling [65]. Another study supported this finding [61] by showing that the soft $(\sim 0.5 \mathrm{kPa})$ substrate was effective in promoting neurogenesis of MSCs whereas the stiff $(\sim 40 \mathrm{pKa})$ one was effective in promoting their osteogenesis. Switching the biophysical microenvironment of MSCs from soft to stiff or stiff to soft substrates led to rewiring the two directions of MSC lineage specification. 
Although the differentiation potential of MSCs into endothelial cells (ECs) remains unclear $[68,69]$, some studies reported possible approaches to differentiate MSCs into ECs $[63,64]$. A previous study demonstrated that a $3 \mathrm{D}$ matrix with tunable properties directed the differentiation of MSC towards vascular cell types [64]. We also applied in situ cross-linkable gelatin hydrogels by conjugating enzymatically cross-linkable hydroxyphenyl propionic acid (GHPA) (Figure 3) [63]. The 3D culture of MSCs in these hydrogels induced vasculogenesis both in vitro and in vivo. Our results showed that GHPA hydrogels induced spontaneous endothelial differentiation of MSC without any soluble factors.

3.3. Surface Topography. When cells are cultured on biomaterial substrates, surface topography is known as a key regulator of cell behavior. Several previous studies reported that surface topographical cues induced direct lineage specification of MSCs [66, 67, 70-72]. Microfeatures (40 $\mu \mathrm{m}$ line, $20 \mu \mathrm{m}$ spacing, and $1 \mu \mathrm{m}$ height) of fibronectin strips printed on a poly(lactic-co-glycolic acid) (PLGA) thin film were found to direct linage commitment of MSCs [66]. In this study, modification of MSC morphology and cytoskeletal arrangement on the patterned film resulted in both neuronal and myogenic lineages, even if myogenic differentiation was dominant when the expression of functional proteins was examined. Along the same line to direct MSC differentiation, Lee et al. fabricated pseudo-3D microwells by templating a hydrazine-immobilized polyacrylamide gel displaying inverse features of circular surface topography via PDMS stamps (circular) [67]. As a result, small circular islands induced an adipogenic phenotype of MSCs while anisotropic geometries induced neurogenic differentiation. Micro- and nanostructured titanium surfaces were used as potential topographical cues to induce osteogenic differentiation of MSCs [71, 72]. The nanotubule-shaped titanium oxide surface structures, which have 70 to $100 \mathrm{~nm}$ titanium oxide nanotube arrays on them, induced cytoskeletal stress and thereby directed osteogenic differentiation of MSCs [71]. It was also reported that osteoblastic differentiation of MSCs was induced on the microstructured titanium surface $(\mathrm{Ra}=$ $3.22 \mu \mathrm{m}$ ) through $\alpha 2 \beta 1$ integrin-mediated interactions with cocultured osteoblasts [72]. Our recent study determined causative roles of topographical cues in directing lineage specification of MSC via patterned graphene surfaces with additional evaluation of electrical stimulation as another cue [70]. Our result showed that expression of osteoprogenitor markers was increased by either (un)patterned graphene substrate or electrical stimulation while the expression of osteoblast makers was increased only when electrical stimulation was applied together with the surface patterns.

\section{Selection of Genetic Factor and Source Cell Type for iPSC Reprogramming}

Induced pluripotent stem cells (iPSCs) were introduced in 2006, which opened a new avenue for stem cell research and regenerative medicine [73]. Obtaining an adequate amount of stem cells is a major limitation for stem cell therapy and research. Previously, classical methods employed to induce pluripotency of somatic cells include somatic cell nuclear transfer (SCNT) and cell fusion. However, limitations associated with oocyte supply, low reprogramming efficiency, and phenotypic abnormalities of the produced animal offspring still hamper the widespread distribution of these classical methods [74].

Resident stem cells in various tissues were also studied as a promising source of stem cells, but the lack of appropriate markers to define their phenotypes and their low differentiation potential were considered as major hurdles for using these cell sources. Hence, the breakthrough idea of reprogramming somatic cells with ectopic pluripotent markers (Sox2, Oct3/4, Klf4, c-Myc, and Lin28) to eventually represent embryonic stem cell (ESC) characteristics was undisputedly attractive [73]. However, it is still controversial whether iPSCs possess the same pluripotency and differentiation ability to ESCs. Donor cell-specific epigenetic signatures remain even after reprogramming and thus generate problematic variations from the expected quality and characteristics of iPSCs in terms of homogeneity and the potential for maturation in stem cell therapy $[75,76]$. Moreover, abnormalities created during the process of iPSC reprogramming, such as stablishing aberrant DNA methylation patterns, were found to increase the heterogeneity in iPSCs $[77,78]$. Additionally, donor-specific genetic variations further increase the heterogeneity of iPSC genetic profiling, such as stablishing aberrant DNA methylation patterns.

4.1. Choice of Vectors for iPSC Reprogramming. Substantial progress has been made in the methodologies to improve the efficiency and efficacy of reprogramming somatic cells to iPSCs in the past decade (Table 4). The type of vectors used to overexpress ectopic pluripotency factors within the target cells are classified into integrating DNA vectors and nonintegrating DNA free vectors. Integrating vectors are further subclassified into insertional vectors including viral and linear DNA delivery systems whereas insertion-free transgene vectors include PiggyBac transposon $[79,80]$ and plasmid/episomal vectors. Recently, nonintegrating systems involving direct protein or microRNA vectors as well as various small molecules are used for reprogramming of somatic cells into iPSCs $[81,82]$. Integrating DNA vectors represent an early generation tool for reprogramming and are still commonly used in experiments owing to their high efficiency. Combinations of retroviral or lentiviral Sox2, Oct4, Klf4, c-Myc, or Lin28 were most popularly used with or without the use of transgene selection markers. Especially, these first-generation viral vectors possess the potential for random insertional mutagenesis, but their undeniable high efficiency still renders them useful for a wide range of iPSC research. Such random insertional mutagenesis contributes to the unpredictability of iPSCs upon in vivo transplantation. Viral promoter-driven fluorescence and cre-LOX expression systems have been used to track and control ectopic gene expression but still generate insertional mutagenesis [83]. In order to overcome problems associated with mutagenesis resulting from ectopic gene insertion, adenoviral, episomal, or plasmid vectors were used as alternatives in the course of developing the next generation of reprogramming methods 
[84, 85]. However, although these alternatives were less prone to mutagenesis associated with ectopic gene integration, the major hindrance was the poor transfection efficiency, displaying efficiencies 1000-10,000 folds lower than those of conventional viral vectors. Further improvement in the reprogramming efficiency was achieved by applying non-DNA methods using Sendai viral vectors, small molecules, Lipofectamine, or miRNA transfections [86-90]. For example, cell membrane-penetrating proteins were tagged with Oct4, Sox2, Klf4, and c-myc for intracellular delivery and cell reprogramming. Human immunodeficiency virus transactivator of transcription (HIV-TAT) protein or polyarginine-tagged pluripotency factors were used to derive mouse and human iPSC lines. However, its low reprogramming efficiency still remains as a major hurdle to overcome [91]. Together, the aforementioned nonintegrating methods are promising to significantly reduce mutagenesis, but their reprogramming efficiencies need to be enhanced further as the efficiencies are still considerably lower $(0.001 \%-)$ compared to integrating vectors $(0.1 \%-1 \%)$. Generating transgene-free iPSCs serves as an attractive alternative because it can compensate for the low transfection efficiency. Addition of small molecules including histone deacetylase (HDAC) inhibitors and other epigenetic modifiers have been reported as representative examples $[92,93]$. On the other hand, the number of ectopic vectors could be reduced by introducing supplementary compounds, where inhibitors of G9a histone methyltransferase could replace either Sox2, Oct4, or c-Myc during reprogramming of neural progenitor cells (NPCs) and fibroblasts in mice [94]. The TGF- $\beta$ receptor antagonist also significantly increased the reprogramming efficiency and kinetics in murine $[95,96]$ and human fibroblasts [97].

It needs to be investigated further whether the type of vectors used to induce pluripotency contributes to the heterogeneity of produced iPSC lines or not. When retrovirus, Sendai virus, and episomal vectors were used for iPSC generation, different reprogramming strategies were applied to obtain human iPSCs. As a result, very similar global gene expression profiles were displayed but subtle differences were observed in the levels of gene expression, indicating that the heterogeneity of produced iPSC lines resulted from clonal signatures rather than the reprogramming method itself [98]. However, even when iPSCs were generated from cells of the same donor, characteristic aberrations in DNA methylation at the epigenomic level were shown to be dependent on the choice of reprogramming factors [99].

As a summary, random DNA aberrations are most notably caused by viral genome integration, leading to iPSC heterogeneity and unpredictability. Thus, nonintegrating systems should be primarily considered as a basic means for differentiation strategies towards clinical applications.

4.2. Donor Cell Characteristics and Stemness. The origin and quality of donor cells are also important factors to ensure successful reprogramming results. In particular, easy access, abundant quantity, and enough replenishment of donor cells after harvesting should be considered when the target donor source is selected.
Donor somatic cell-specific transcriptional and epigenetic signatures significantly contribute to the heterogeneity of efficiency and efficacy in reprogramming and differentiation of iPSCs (Table 5). The most widely used cell source for reprogramming into iPSCs is dermal fibroblasts, most frequently harvested from neonates as well as adults [73]. Keratinocytes (a type of bone marrow cells), peripheral blood cells (a type of $\mathrm{CD} 34^{+}$peripheral blood mononuclear cells), amniotic fluid cells, cord blood stem cells, endometrial stromal fibroblasts, and dental pulp cells have been reported as reliable sources of somatic cells for reprogramming (Figure 4) [100-106]. Moreover, it has been reported, even in cells which were originated from the same donor but from different organs, that the tissue-specific epigenetic signatures affect the heterogeneity of efficiency and efficacy in reprogramming and the differentiation potential of iPSC lines. Such observations were prominent in the early passages when the reprogramming process is not yet complete [107-109].

If stemness is enhanced, the negative effect of tissuespecific epigenetic signature may be attenuated during the process of serial passaging while losing the epigenetic memory sequentially. Characteristic DNA methylation patterns are originated from the donor cells and thus can be tracked in specific iPSC clones. Consequently, limitations in stemness of iPSCs as opposed to the full pluripotency of embryonic stem cells are inevitable. Experimental techniques to overcome the gap between the epigenetic memory of the donor cell and the stemness of the derived iPSC lines have been described in previous studies $[110,111]$. One strategy is to increase the iPSC passage number while another approach is to introduce chromatin-modifying substances, which diminishes the epigenetic memory and enhances stemness. The process of acquiring pluripotency may not be complete upon immediate silencing expression of exogenous pluripotency factors but may continue for several rounds of cell passaging. iPSCs exhibit considerable differences in their telomere length and the global pattern of transcription and DNA methylation $[110,112,113]$. On the other hand, transgenes are usually silenced in the process of reprogramming by de novo methylation. When this process is not fully accomplished, gaining the pluripotency of the reprogrammed cells primarily relies on the exogenously introduced factors. When the endogenous pluripotent genes are halted from being fully expressed, these colonies are defined as "partially reprogrammed." Within such colonies, pluripotency is frequently not fully acquired even after the exogenous factors are eventually turned off $[114,115]$. Conversely, when ectopic transgenes are not silenced and exposed to residual activities or reactivation of the viral transgenes in the iPSC cells, tumor formation occurs as demonstrated in chimera experiments [73]. Other potential causes of epigenetic differences have also been attributed to either aberrant or incomplete reprogramming or even by various cell culture conditions [77, 116-119].

\section{Conclusion}

Although a growing body of evidence suggests stem cells as a promising candidate for cell therapy in the position of 
replacing somatic cells, the aforementioned issues regarding senescence and low differentiation efficiency must be addressed for successful clinical applications. In this review, we introduced state-of-the-art methods which are currently approached to improve efficiency and efficacy of stemness maintenance, direct differentiation, and iPSC reprogramming, with the minimal use of expensive and side effectoccurring growth factors. Biophysical stimulation, organic compound treatment, genetic transfection, and various types of biomaterials were employed to achieve the purposes. In particular, the effects of matrix stiffness, improving cell-cell interaction, and antioxidant treatment became a major part of interest. Additionally, biomaterials with specific composition, stiffness, and topography can serve as a promising toolbox to guide direct differentiation of stem cells. Finally, several combinations or individual uses of genetic factors to induce reprogramming of somatic cells were introduced as a means of generating iPSCs. Pros and cons of major reprogramming methods were discussed as well. Taken together, selection of biomaterials or other external factors needs to be customized for targetspecific developments and application of stem cell therapy towards successful clinical applications.

\section{Conflicts of Interest}

The authors declare that they have no conflicts of interest.

\section{Acknowledgments}

This study was financially supported by the Basic Science Research Program through the National Research Foundation of Korea (NRF) funded by the Ministry of Science, ICT and Future Planning (NRF-2016M3A9E9941743 and 2017M3A9E9087117).

\section{References}

[1] O. Ringdén, M. Uzunel, I. Rasmusson et al., "Mesenchymal stem cells for treatment of therapy-resistant graft-versushost disease," Transplantation, vol. 81, no. 10, pp. 13901397, 2006.

[2] D. Polchert, J. Sobinsky, G. Douglas et al., "IFN- $\gamma$ activation of mesenchymal stem cells for treatment and prevention of graft versus host disease," European Journal of Immunology, vol. 38, no. 6, pp. 1745-1755, 2008.

[3] R. Yanez, M. L. Lamana, J. Garcia-Castro, I. Colmenero, M. Ramirez, and J. A. Bueren, "Adipose tissue-derived mesenchymal stem cells have in vivo immunosuppressive properties applicable for the control of the graft-versus-host disease," Stem Cells, vol. 24, no. 11, pp. 2582-2591, 2006.

[4] E. J. Koay and K. A. Athanasiou, "Development of serumfree, chemically defined conditions for human embryonic stem cell-derived fibrochondrogenesis," Tissue Engineering Part A, vol. 15, no. 8, pp. 2249-2257, 2009.

[5] L. A. Solchaga, K. Penick, J. D. Porter, V. M. Goldberg, A. I. Caplan, and J. F. Welter, "FGF-2 enhances the mitotic and chondrogenic potentials of human adult bone marrowderived mesenchymal stem cells," Journal of Cellular Physiology, vol. 203, no. 2, pp. 398-409, 2005.
[6] S. Tsutsumi, A. Shimazu, K. Miyazaki et al., "Retention of multilineage differentiation potential of mesenchymal cells during proliferation in response to FGF," Biochemical and Biophysical Research Communications, vol. 288, no. 2, pp. 413-419, 2001.

[7] D. James, A. J. Levine, D. Besser, and A. Hemmati-Brivanlou, "TGF $\beta /$ activin/nodal signaling is necessary for the maintenance of pluripotency in human embryonic stem cells," Development, vol. 132, no. 6, pp. 1273-1282, 2005.

[8] M. Sakaki-Yumoto, Y. Katsuno, and R. Derynck, "TGF- $\beta$ family signaling in stem cells," Biochimica et Biophysica Acta (BBA)-General Subjects, vol. 1830, no. 2, pp. 2280-2296, 2013.

[9] H. M. van Beuningen, H. L. Glansbeek, P. M. van der Kraan, and W. B. van den Berg, "Differential effects of local application of BMP- 2 or TGF- $\beta 1$ on both articular cartilage composition and osteophyte formation," Osteoarthritis and Cartilage, vol. 6, no. 5, pp. 306-317, 1998.

[10] L. Z. Sailor, R. M. Hewick, and E. A. Morris, "Recombinant human bone morphogenetic protein-2 maintains the articular chondrocyte phenotype in long-term culture," Journal of Orthopaedic Research, vol. 14, no. 6, pp. 937945, 1996.

[11] C. A. Hellingman, W. Koevoet, N. Kops et al., "Fibroblast growth factor receptors in in vitro and in vivo chondrogenesis: relating tissue engineering using adult mesenchymal stem cells to embryonic development," Tissue Engineering Part A, vol. 16, no. 2, pp. 545-556, 2010.

[12] A. De Becker and I. Van Riet, "Homing and migration of mesenchymal stromal cells: how to improve the efficacy of cell therapy?," World Journal of Stem Cells, vol. 8, no. 3, pp. 73-87, 2016.

[13] H. M. Lazarus, S. E. Haynesworth, S. L. Gerson, N. S. Rosenthal, and A. I. Caplan, "Ex vivo expansion and subsequent infusion of human bone marrow-derived stromal progenitor cells (mesenchymal progenitor cells): implications for therapeutic use," Bone Marrow Transplantation, vol. 16, no. 4, pp. 557-564, 1995.

[14] S. P. Bruder, N. Jaiswal, and S. E. Haynesworth, "Growth kinetics, self-renewal, and the osteogenic potential of purified human mesenchymal stem cells during extensive subcultivation and following cryopreservation," Journal of Cellular Biochemistry, vol. 64, no. 2, pp. 278-294, 1997.

[15] K. Ksiazek, "A comprehensive review on mesenchymal stem cell growth and senescence," Rejuvenation Research, vol. 12, no. 2, pp. 105-116, 2009.

[16] J. Lam, S. Lu, E. J. Lee et al., "Osteochondral defect repair using bilayered hydrogels encapsulating both chondrogenically and osteogenically pre-differentiated mesenchymal stem cells in a rabbit model," Osteoarthritis and Cartilage, vol. 22, no. 9, pp. 1291-1300, 2014.

[17] F. Barry, R. E. Boynton, B. Liu, and J. M. Murphy, "Chondrogenic differentiation of mesenchymal stem cells from bone marrow: differentiation-dependent gene expression of matrix components," Experimental Cell Research, vol. 268, no. 2, pp. 189-200, 2001.

[18] H. J. Lee, B. H. Choi, B. H. Min, and S. R. Park, "Low-intensity ultrasound inhibits apoptosis and enhances viability of human mesenchymal stem cells in three-dimensional alginate culture during chondrogenic differentiation," Tissue Engineering, vol. 13, no. 5, pp. 1049-1057, 2007.

[19] K. Park, K. J. Cho, J. J. Kim, I. H. Kim, and D. K. Han, "Functional PLGA scaffolds for chondrogenesis of bone-marrow- 
derived mesenchymal stem cells," Macromolecular Bioscience, vol. 9, no. 3, pp. 221-229, 2009.

[20] F. Padilla, R. Puts, L. Vico, A. Guignandon, and K. Raum, "Stimulation of bone repair with ultrasound," Advances in Experimental Medicine and Biology, vol. 880, pp. 385-427, 2016.

[21] R. T. Brady, F. J. O'Brien, and D. A. Hoey, "Mechanically stimulated bone cells secrete paracrine factors that regulate osteoprogenitor recruitment, proliferation, and differentiation," Biochemical and Biophysical Research Communications, vol. 459, no. 1, pp. 118-123, 2015.

[22] M. J. Go, C. Takenaka, and H. Ohgushi, "Forced expression of Sox 2 or Nanog in human bone marrow derived mesenchymal stem cells maintains their expansion and differentiation capabilities," Experimental Cell Research, vol. 314, no. 5, pp. 1147-1154, 2008.

[23] D. S. Yoon, Y. H. Kim, H. S. Jung, S. Paik, and J. W. Lee, "Importance of Sox 2 in maintenance of cell proliferation and multipotency of mesenchymal stem cells in lowdensity culture," Cell Proliferation, vol. 44, no. 5, pp. 428440, 2011.

[24] T. M. Liu, Y. N. Wu, X. M. Guo, J. H. P. Hui, E. H. Lee, and B. Lim, "Effects of ectopic Nanog and Oct4 overexpression on mesenchymal stem cells," Stem Cells and Development, vol. 18, no. 7, pp. 1013-1022, 2009.

[25] M. Ranzani, D. Cesana, C. C. Bartholomae et al., "Lentiviral vector-based insertional mutagenesis identifies genes associated with liver cancer," Nature Methods, vol. 10, no. 2, pp. 155-161, 2013.

[26] H. Chen, X. Liu, W. Zhu et al., "SIRT1 ameliorates age-related senescence of mesenchymal stem cells via modulating telomere shelterin," Frontiers in Aging Neuroscience, vol. 6, p. 103, 2014.

[27] D. S. Yoon, Y. Choi, Y. Jang et al., "SIRT1 directly regulates SOX2 to maintain self-renewal and multipotency in bone marrow-derived mesenchymal stem cells," Stem Cells, vol. 32, no. 12, pp. 3219-3231, 2014.

[28] D. S. Yoon, Y. Choi, S. M. Choi, K. H. Park, and J. W. Lee, "Different effects of resveratrol on early and late passage mesenchymal stem cells through $\beta$-catenin regulation," Biochemical and Biophysical Research Communications, vol. 467, no. 4, pp. 1026-1032, 2015.

[29] D. Harman, "Aging: a theory based on free radical and radiation chemistry," Journal of Gerontology, vol. 11, no. 3, pp. 298-300, 1956.

[30] W. Zhu, J. Chen, X. Cong, S. Hu, and X. Chen, "Hypoxia and serum deprivation-induced apoptosis in mesenchymal stem cells," Stem Cells, vol. 24, no. 2, pp. 416-425, 2006.

[31] S. Sart, L. Song, and Y. Li, "Controlling redox status for stem cell survival, expansion, and differentiation," Oxidative Medicine and Cellular Longevity, vol. 2015, Article ID 105135, 14 pages, 2015.

[32] Y.-J. Surh, J. Kundu, and H.-K. Na, "Nrf2 as a master redox switch in turning on the cellular signaling involved in the induction of cytoprotective genes by some chemopreventive phytochemicals," Planta Medica, vol. 74, no. 13, pp. 15261539, 2008.

[33] H. Zhu, L. Zhang, K. Itoh et al., "Nrf2 controls bone marrow stromal cell susceptibility to oxidative and electrophilic stress," Free Radical Biology \& Medicine, vol. 41, no. 1, pp. 132-143, 2006.
[34] S. Nemoto, M. M. Fergusson, and T. Finkel, "Nutrient availability regulates SIRT1 through a forkhead-dependent pathway," Science, vol. 306, no. 5704, pp. 2105-2108, 2004.

[35] D. S. Yoon, Y. Choi, and J. W. Lee, "Cellular localization of NRF2 determines the self-renewal and osteogenic differentiation potential of human MSCs via the P53-SIRT1 axis," Cell Death \& Disease, vol. 7, no. 2, article e2093, 2016.

[36] N. Z. Kuhn and R. S. Tuan, "Regulation of stemness and stem cell niche of mesenchymal stem cells: implications in tumorigenesis and metastasis," Journal of Cellular Physiology, vol. 222, no. 2, pp. 268-277, 2010.

[37] M. F. Brizzi, G. Tarone, and P. Defilippi, "Extracellular matrix, integrins, and growth factors as tailors of the stem cell niche," Current Opinion in Cell Biology, vol. 24, no. 5, pp. 645-651, 2012.

[38] S. r. Pattabhi, J. S. Martinez, and T. C. S. Keller III, "Decellularized ECM effects on human mesenchymal stem cell stemness and differentiation," Differentiation, vol. 88, no. 4-5, pp. 131-143, 2014.

[39] Y. Xiong, J. He, W. Zhang, G. Zhou, Y. Cao, and W. Liu, "Retention of the stemness of mouse adipose-derived stem cells by their expansion on human bone marrow stromal cell-derived extracellular matrix," Tissue Engineering Part A, vol. 21, no. 11-12, pp. 1886-1894, 2015.

[40] R. Rakian, T. J. Block, S. M. Johnson et al., "Native extracellular matrix preserves mesenchymal stem cell "stemness" and differentiation potential under serum-free culture conditions," Stem Cell Research \& Therapy, vol. 6, no. 1, p. 235, 2015.

[41] B. Antebi, Z. Zhang, Y. Wang, Z. Lu, X. D. Chen, and J. Ling, "Stromal-cell-derived extracellular matrix promotes the proliferation and retains the osteogenic differentiation capacity of mesenchymal stem cells on three-dimensional scaffolds," Tissue Engineering Part C: Methods, vol. 21, no. 2, pp. 171$181,2015$.

[42] J. Zhang, B. Li, and J. H.-C. Wang, "The role of engineered tendon matrix in the stemness of tendon stem cells in vitro and the promotion of tendon-like tissue formation in vivo," Biomaterials, vol. 32, no. 29, pp. 6972-6981, 2011.

[43] J. Lee, A. A. Abdeen, A. S. Kim, and K. A. Kilian, "Influence of biophysical parameters on maintaining the mesenchymal stem cell phenotype," ACS Biomaterials Science \& Engineering, vol. 1, no. 4, pp. 218-226, 2015.

[44] S. Ansari, P. Sarrion, M. M. Hasani-Sadrabadi, T. Aghaloo, B. M. Wu, and A. Moshaverinia, "Regulation of the fate of dental-derived mesenchymal stem cells using engineered alginate-GelMA hydrogels," Journal of Biomedical Materials Research Part A, vol. 105, no. 11, pp. 2957-2967, 2017.

[45] K. C. Rustad, V. W. Wong, M. Sorkin et al., "Enhancement of mesenchymal stem cell angiogenic capacity and stemness by a biomimetic hydrogel scaffold," Biomaterials, vol. 33, no. 1, pp. 80-90, 2012.

[46] H.-W. Chien, S.-W. Fu, A.-Y. Shih, and W.-B. Tsai, "Modulation of the stemness and osteogenic differentiation of human mesenchymal stem cells by controlling RGD concentrations of poly(carboxybetaine) hydrogel," Biotechnology Journal, vol. 9, no. 12, pp. 1613-1623, 2014.

[47] R. J. McMurray, N. Gadegaard, P. M. Tsimbouri et al., "Nanoscale surfaces for the long-term maintenance of mesenchymal stem cell phenotype and multipotency," Nature Materials, vol. 10, no. 8, pp. 637-644, 2011. 
[48] F. Zhao, J. J. Veldhuis, Y. Duan et al., "Low oxygen tension and synthetic nanogratings improve the uniformity and stemness of human mesenchymal stem cell layer," Molecular Therapy, vol. 18, no. 5, pp. 1010-1018, 2010.

[49] K. S. Park, J. Ahn, J. Y. Kim, H. Park, H. O. Kim, and S. H. Lee, "Poly-L-lysine increases the ex vivo expansion and erythroid differentiation of human hematopoietic stem cells, as well as erythroid enucleation efficacy," Tissue Engineering Part A, vol. 20, no. 5-6, pp. 1072-1080, 2014.

[50] J. S. Heo, H. O. Kim, S. Y. Song, D. H. Lew, Y. Choi, and S. Kim, "Poly-L-lysine prevents senescence and augments growth in culturing mesenchymal stem cells ex vivo," BioMed Research International, vol. 2016, Article ID 8196078, 13 pages, 2016.

[51] L. H. Hofmeister, L. Costa, D. A. Balikov et al., "Patterned polymer matrix promotes stemness and cell-cell interaction of adult stem cells," Journal of Biological Engineering, vol. 9, no. 1, p. 18, 2015.

[52] D. A. Balikov, S. W. Crowder, T. C. Boire et al., "Tunable surface repellency maintains stemness and redox capacity of human mesenchymal stem cells," ACS Applied Materials \& Interfaces, vol. 9, no. 27, pp. 22994-23006, 2017.

[53] K. Nejati-Koshki, Y. Pilehvar-Soltanahmadi, E. Alizadeh, A. Ebrahimi-Kalan, Y. Mortazavi, and N. Zarghami, "Development of Emu oil-loaded PCL/collagen bioactive nanofibers for proliferation and stemness preservation of human adipose-derived stem cells: possible application in regenerative medicine," Drug Development and Industrial Pharmacy, vol. 43, no. 12, pp. 1978-1988, 2017.

[54] L. Pandolfi, N. T. Furman, X. Wang et al., "A nanofibrous electrospun patch to maintain human mesenchymal cell stemness," Journal of Materials Science: Materials in Medicine, vol. 28, no. 3, p. 44, 2017.

[55] Y. Pilehvar-Soltanahmadi, M. Nouri, M. M. Martino et al., "Cytoprotection, proliferation and epidermal differentiation of adipose tissue-derived stem cells on emu oil based electrospun nanofibrous mat," Experimental Cell Research, vol. 357, no. 2, pp. 192-201, 2017.

[56] N. C. Cheng, S. Wang, and T. H. Young, "The influence of spheroid formation of human adipose-derived stem cells on chitosan films on stemness and differentiation capabilities," Biomaterials, vol. 33, no. 6, pp. 1748-1758, 2012.

[57] T. Taguchi, J. Y. Cho, J. Hao, Y. S. Nout-Lomas, K. S. Kang, and D. J. Griffon, "Influence of hypoxia on the stemness of umbilical cord matrix-derived mesenchymal stem cells cultured on chitosan films," Journal of Biomedical Materials Research Part B: Applied Biomaterials, vol. 106, no. 2, pp. 501-511, 2018.

[58] J. L. Robinson, M. A. P. McEnery, H. Pearce et al., "Osteoinductive PolyHIPE foams as injectable bone grafts," Tissue Engineering Part A, vol. 22, no. 5-6, pp. 403-414, 2016.

[59] S. W. Crowder, D. Prasai, R. Rath et al., "Three-dimensional graphene foams promote osteogenic differentiation of human mesenchymal stem cells," Nanoscale, vol. 5, no. 10, pp. 41714176, 2013.

[60] J. Lee, A. A. Abdeen, and K. A. Kilian, "Rewiring mesenchymal stem cell lineage specification by switching the biophysical microenvironment," Scientific Reports, vol. 4, no. 1, p. $5188,2014$.

[61] R. Olivares-Navarrete, E. M. Lee, K. Smith et al., "Substrate stiffness controls osteoblastic and condrocytic differentiation of mesenchymal stem cells without exogenous stimuli," PLoS One, vol. 12, no. 1, article e0170312, 2017.

[62] A. Islam, M. Younesi, T. Mbimba, and O. Akkus, "Collagen substrate stiffness anisotropy affects cellular elongation, nuclear shape, and stem cell fate toward anisotropic tissue lineage," Advanced Healthcare Materials, vol. 5, no. 17, pp. 2237-2247, 2016.

[63] S. H. Lee, Y. Lee, Y. W. Chun et al., "In situ crosslinkable gelatin hydrogels for vasculogenic induction and delivery of mesenchymal stem cells," Advanced Functional Materials, vol. 24, no. 43, pp. 6771-6781, 2014.

[64] G. Zhang, C. T. Drinnan, L. R. Geuss, and L. J. Suggs, "Vascular differentiation of bone marrow stem cells is directed by a tunable three-dimensional matrix," Acta Biomaterialia, vol. 6, no. 9, pp. 3395-3403, 2010.

[65] T. D. Ross, B. G. Coon, S. Yun et al., "Integrins in mechanotransduction," Current Opinion in Cell Biology, vol. 25, no. 5, pp. 613-618, 2013.

[66] C. Y. Tay, H. Yu, M. Pal et al., "Micropatterned matrix directs differentiation of human mesenchymal stem cells towards myocardial lineage," Experimental Cell Research, vol. 316, no. 7, pp. 1159-1168, 2010.

[67] J. Lee, A. A. Abdeen, D. Zhang, and K. A. Kilian, "Directing stem cell fate on hydrogel substrates by controlling cell geometry, matrix mechanics and adhesion ligand composition," Biomaterials, vol. 34, no. 33, pp. 8140-8148, 2013.

[68] M. P. Alfaro, S. Saraswati, and P. P. Young, "Chapter two molecular mediators of mesenchymal stem cell biology," Vitamins \& Hormones, vol. 87, pp. 39-59, 2011.

[69] J. Wagner, T. Kean, R. Young, J. E. Dennis, and A. I. Caplan, "Optimizing mesenchymal stem cell-based therapeutics," Current Opinion in Biotechnology, vol. 20, no. 5, pp. 531536, 2009.

[70] D. A. Balikov, B. Fang, Y. W. Chun et al., "Directing lineage specification of human mesenchymal stem cells by decoupling electrical stimulation and physical patterning on unmodified graphene," Nanoscale, vol. 8, no. 28, pp. 13730 13739, 2016.

[71] S. Oh, K. S. Brammer, Y. S. J. Li et al., "Stem cell fate dictated solely by altered nanotube dimension," Proceedings of the National Academy of Sciences of the United States of America, vol. 106, no. 7, pp. 2130-2135, 2009.

[72] R. Olivares-Navarrete, S. L. Hyzy, D. L. Hutton et al., "Direct and indirect effects of microstructured titanium substrates on the induction of mesenchymal stem cell differentiation towards the osteoblast lineage," Biomaterials, vol. 31, no. 10, pp. 2728-2735, 2010.

[73] K. Takahashi and S. Yamanaka, "Induction of pluripotent stem cells from mouse embryonic and adult fibroblast cultures by defined factors," Cell, vol. 126, no. 4, pp. 663-676, 2006.

[74] T. Wakayama and R. Yanagimachi, "Cloning of male mice from adult tail-tip cells," Nature Genetics, vol. 22, no. 2, pp. 127-128, 1999.

[75] R. Lister, M. Pelizzola, Y. S. Kida et al., "Hotspots of aberrant epigenomic reprogramming in human induced pluripotent stem cells," Nature, vol. 471, no. 7336, pp. 68-73, 2011.

[76] D. S. Kim, J. S. Lee, J. W. Leem et al., "Robust enhancement of neural differentiation from human ES and iPS cells regardless of their innate difference in differentiation propensity," Stem Cell Reviews, vol. 6, no. 2, pp. 270-281, 2010. 
[77] M. Stadtfeld, E. Apostolou, H. Akutsu et al., "Aberrant silencing of imprinted genes on chromosome $12 \mathrm{qF} 1$ in mouse induced pluripotent stem cells," Nature, vol. 465, no. 7295, pp. 175-181, 2010.

[78] K. L. Nazor, G. Altun, C. Lynch et al., "Recurrent variations in DNA methylation in human pluripotent stem cells and their differentiated derivatives," Cell Stem Cell, vol. 10, no. 5, pp. 620-634, 2012.

[79] K. Kaji, K. Norrby, A. Paca, M. Mileikovsky, P. Mohseni, and K. Woltjen, "Virus-free induction of pluripotency and subsequent excision of reprogramming factors," Nature, vol. 458, no. 7239, pp. 771-775, 2009.

[80] K. Woltjen, I. P. Michael, P. Mohseni et al., "piggyBac transposition reprograms fibroblasts to induced pluripotent stem cells," Nature, vol. 458, no. 7239, pp. 766-770, 2009.

[81] K. Okita, T. Ichisaka, and S. Yamanaka, "Generation of germline-competent induced pluripotent stem cells," Nature, vol. 448, no. 7151, pp. 313-317, 2007.

[82] M. Nakagawa, M. Koyanagi, K. Tanabe et al., "Generation of induced pluripotent stem cells without Myc from mouse and human fibroblasts," Nature Biotechnology, vol. 26, no. 1, pp. 101-106, 2008.

[83] S. Chakraborty, N. Christoforou, A. Fattahi, R. W. Herzog, and K. W. Leong, "A robust strategy for negative selection of Cre-loxP recombination-based excision of transgenes in induced pluripotent stem cells," PLoS One, vol. 8, no. 5, article e64342, 2013.

[84] M. Stadtfeld and K. Hochedlinger, "Induced pluripotency: history, mechanisms, and applications," Genes \& Development, vol. 24, no. 20, pp. 2239-2263, 2010.

[85] W. Zhou and C. R. Freed, “Adenoviral gene delivery can reprogram human fibroblasts to induced pluripotent stem cells," Stem Cells, vol. 27, no. 11, pp. 2667-2674, 2009.

[86] Y. Zhang, W. Li, T. Laurent, and S. Ding, "Small molecules, big roles - the chemical manipulation of stem cell fate and somatic cell reprogramming," Journal of Cell Science, vol. 125, no. 23, pp. 5609-5620, 2012.

[87] J. Yu, K. Hu, K. Smuga-Otto et al., "Human induced pluripotent stem cells free of vector and transgene sequences," Science, vol. 324, no. 5928, pp. 797-801, 2009.

[88] H. Ban, N. Nishishita, N. Fusaki et al., "Efficient generation of transgene-free human induced pluripotent stem cells (iPSCs) by temperature-sensitive Sendai virus vectors," Proceedings of the National Academy of Sciences of the United States of America, vol. 108, no. 34, pp. 14234-14239, 2011.

[89] M. Nakanishi and M. Otsu, "Development of Sendai virus vectors and their potential applications in gene therapy and regenerative medicine," Current Gene Therapy, vol. 12, no. 5, pp. 410-416, 2012.

[90] Y. Shi, C. Desponts, J. T. Do, H. S. Hahm, H. R. Scholer, and S. Ding, "Induction of pluripotent stem cells from mouse embryonic fibroblasts by Oct4 and Klf4 with small-molecule compounds," Cell Stem Cell, vol. 3, no. 5, pp. 568-574, 2008.

[91] E. J. Kim, G. Shim, K. Kim, I. C. Kwon, Y. K. Oh, and C. K. Shim, "Hyaluronic acid complexed to biodegradable poly Larginine for targeted delivery of siRNAs," The Journal of Gene Medicine, vol. 11, no. 9, pp. 791-803, 2009.

[92] D. Huangfu, R. Maehr, W. Guo et al., "Induction of pluripotent stem cells by defined factors is greatly improved by small-molecule compounds," Nature Biotechnology, vol. 26, no. 7, pp. 795-7, 2008.
[93] D. Huangfu, K. Osafune, R. Maehr et al., "Induction of pluripotent stem cells from primary human fibroblasts with only Oct4 and Sox2," Nature Biotechnology, vol. 26, no. 11, pp. 1269-1275, 2008.

[94] Y. Shi, J. Tae Do, C. Desponts, H. S. Hahm, H. R. Schöler, and S. Ding, "A combined chemical and genetic approach for the generation of induced pluripotent stem cells," Cell Stem Cell, vol. 2, no. 6, pp. 525-528, 2008.

[95] J. K. Ichida, J. Blanchard, K. Lam et al., “A small-molecule inhibitor of tgf- $\beta$ signaling replaces Sox 2 in reprogramming by inducing Nanog," Cell Stem Cell, vol. 5, no. 5, pp. 491503, 2009.

[96] N. Maherali and K. Hochedlinger, "Tgf $\beta$ signal inhibition cooperates in the induction of iPSCs and replaces Sox 2 and cMyc," Current Biology, vol. 19, no. 20, pp. 1718-1723, 2009.

[97] W. Li, W. Wei, S. Zhu et al., "Generation of rat and human induced pluripotent stem cells by combining genetic reprogramming and chemical inhibitors," Cell Stem Cell, vol. 4, no. 1, pp. 16-19, 2009.

[98] M. Trevisan, G. Desole, G. Costanzi, E. Lavezzo, G. Palu, and L. Barzon, "Reprogramming methods do not affect gene expression profile of human induced pluripotent stem cells," International Journal of Molecular Sciences, vol. 18, no. 1, 2017.

[99] A. C. Planello, J. Ji, V. Sharma et al., "Aberrant DNA methylation reprogramming during induced pluripotent stem cell generation is dependent on the choice of reprogramming factors," Cell Regeneration, vol. 3, no. 1, p. 4, 2014.

[100] J. H. Park, L. Daheron, S. Kantarci, B. S. Lee, and J. M. Teixeira, "Human endometrial cells express elevated levels of pluripotent factors and are more amenable to reprogramming into induced pluripotent stem cells," Endocrinology, vol. 152, no. 3, pp. 1080-1089, 2011.

[101] T. Aasen, A. Raya, M. J. Barrero et al., "Efficient and rapid generation of induced pluripotent stem cells from human keratinocytes," Nature Biotechnology, vol. 26, no. 11, pp. 1276-1284, 2008.

[102] J. Hanna, S. Markoulaki, P. Schorderet et al., "Direct reprogramming of terminally differentiated mature B lymphocytes to pluripotency," Cell, vol. 133, no. 2, pp. 250264, 2008.

[103] T. Aoi, K. Yae, M. Nakagawa et al., "Generation of pluripotent stem cells from adult mouse liver and stomach cells," Science, vol. 321, no. 5889, pp. 699-702, 2008.

[104] Y. H. Loh, S. Agarwal, I. H. Park et al., "Generation of induced pluripotent stem cells from human blood," Blood, vol. 113, no. 22, pp. 5476-5479, 2009.

[105] C. Li, J. Zhou, G. Shi et al., "Pluripotency can be rapidly and efficiently induced in human amniotic fluid-derived cells," Human Molecular Genetics, vol. 18, no. 22, pp. 4340-4349, 2009.

[106] N. Tamaoki, K. Takahashi, T. Tanaka et al., "Dental pulp cells for induced pluripotent stem cell banking," Journal of Dental Research, vol. 89, no. 8, pp. 773-8, 2010.

[107] Z. Ghosh, K. D. Wilson, Y. Wu, S. Hu, T. Quertermous, and J. C. $\mathrm{Wu}$, "Persistent donor cell gene expression among human induced pluripotent stem cells contributes to differences with human embryonic stem cells," PLoS One, vol. 5, no. 2, article e8975, 2010.

[108] M. C. N. Marchetto, G. W. Yeo, O. Kainohana, M. Marsala, F. H. Gage, and A. R. Muotri, "Transcriptional signature 
and memory retention of human-induced pluripotent stem cells," PLoS One, vol. 4, no. 9, article e7076, 2009.

[109] K. Kim, R. Zhao, A. Doi et al., "Donor cell type can influence the epigenome and differentiation potential of human induced pluripotent stem cells," Nature Biotechnology, vol. 29, no. 12, pp. 1117-1119, 2011.

[110] J. Utikal, J. M. Polo, M. Stadtfeld et al., "Immortalization eliminates a roadblock during cellular reprogramming into iPS cells," Nature, vol. 460, no. 7259, pp. 1145-1148, 2009.

[111] K. Kim, A. Doi, B. Wen et al., "Epigenetic memory in induced pluripotent stem cells," Nature, vol. 467, no. 7313, pp. 285290, 2010.

[112] R. M. Marion, K. Strati, H. Li et al., “A p53-mediated DNA damage response limits reprogramming to ensure iPS cell genomic integrity," Nature, vol. 460, no. 7259, pp. 11491153, 2009.

[113] R. M. Marion, K. Strati, H. Li et al., "Telomeres acquire embryonic stem cell characteristics in induced pluripotent stem cells," Cell Stem Cell, vol. 4, no. 2, pp. 141-154, 2009.

[114] M. Stadtfeld, M. Nagaya, J. Utikal, G. Weir, and K. Hochedlinger, "Induced pluripotent stem cells generated without viral integration," Science, vol. 322, no. 5903, pp. 945-949, 2008.

[115] R. Sridharan, J. Tchieu, M. J. Mason et al., "Role of the murine reprogramming factors in the induction of pluripotency," Cell, vol. 136, no. 2, pp. 364-377, 2009.

[116] A. M. Newman and J. B. Cooper, "Lab-specific gene expression signatures in pluripotent stem cells," Cell Stem Cell, vol. 7, no. 2, pp. 258-262, 2010.

[117] T. L. Chung, R. M. Brena, G. Kolle et al., "Vitamin C promotes widespread yet specific DNA demethylation of the epigenome in human embryonic stem cells," Stem Cells, vol. 28, no. 10, pp. 1848-1855, 2010.

[118] T. L. Chung, J. P. Turner, N. Y. Thaker et al., "Ascorbate promotes epigenetic activation of CD30 in human embryonic stem cells," Stem Cells, vol. 28, no. 10, pp. 1782-1793, 2010.

[119] Y. Ohi, H. Qin, C. Hong et al., "Incomplete DNA methylation underlies a transcriptional memory of somatic cells in human iPS cells," Nature Cell Biology, vol. 13, no. 5, pp. 541-549, 2011.

[120] N. Singh, S. S. Rahatekar, K. K. K. Koziol et al., "Directing chondrogenesis of stem cells with specific blends of cellulose and silk," Biomacromolecules, vol. 14, no. 5, pp. 1287-1298, 2013.

[121] C. Cristallini, E. Cibrario Rocchietti, L. Accomasso et al., "The effect of bioartificial constructs that mimic myocardial structure and biomechanical properties on stem cell commitment towards cardiac lineage," Biomaterials, vol. 35 , no. 1, pp. 92$104,2014$.

[122] C. M. Murphy, A. Matsiko, M. G. Haugh, J. P. Gleeson, and F. J. O'Brien, "Mesenchymal stem cell fate is regulated by the composition and mechanical properties of collagen-glycosaminoglycan scaffolds," Journal of the Mechanical Behavior of Biomedical Materials, vol. 11, pp. 53-62, 2012.

[123] E. Mooney, J. N. Mackle, D. J. P. Blond et al., "The electrical stimulation of carbon nanotubes to provide a cardiomimetic cue to MSCs," Biomaterials, vol. 33, no. 26, pp. 6132-6139, 2012.

[124] L. Glennon-Alty, R. Williams, S. Dixon, and P. Murray, "Induction of mesenchymal stem cell chondrogenesis by polyacrylate substrates," Acta Biomaterialia, vol. 9, no. 4, pp. 6041-6051, 2013.

[125] I. H. Park, R. Zhao, J. A. West et al., "Reprogramming of human somatic cells to pluripotency with defined factors," Nature, vol. 451, no. 7175, pp. 141-146, 2008.

[126] B. K. Chou, P. Mali, X. Huang et al., "Efficient human iPS cell derivation by a non-integrating plasmid from blood cells with unique epigenetic and gene expression signatures," Cell Research, vol. 21, no. 3, pp. 518-529, 2011.

[127] F. Jia, K. D. Wilson, N. Sun et al., "A nonviral minicircle vector for deriving human iPS cells," Nature Methods, vol. 7, no. 3, pp. 197-199, 2010.

[128] L. Warren, P. D. Manos, T. Ahfeldt et al., "Highly efficient reprogramming to pluripotency and directed differentiation of human cells with synthetic modified mRNA," Cell Stem Cell, vol. 7, no. 5, pp. 618-630, 2010.

[129] M. Silva, L. Daheron, H. Hurley et al., "Generating iPSCs: translating cell reprogramming science into scalable and robust biomanufacturing strategies," Cell Stem Cell, vol. 16, no. 1, pp. 13-17, 2015.

[130] D. Kim, C. H. Kim, J. I. Moon et al., "Generation of human induced pluripotent stem cells by direct delivery of reprogramming proteins," Cell Stem Cell, vol. 4, no. 6, pp. 472-6, 2009.

[131] Q. Zhou, J. Brown, A. Kanarek, J. Rajagopal, and D. A. Melton, "In vivo reprogramming of adult pancreatic exocrine cells to $\beta$-cells," Nature, vol. 455, no. 7213, pp. 627-632, 2008.

[132] K. Wolfrum, Y. Wang, A. Prigione, K. Sperling, H. Lehrach, and J. Adjaye, "The LARGE principle of cellular reprogramming: lost, acquired and retained gene expression in foreskin and amniotic fluid-derived human iPS cells," PLoS One, vol. 5, no. 10, article e13703, 2010.

[133] S. N. Dowey, X. Huang, B. K. Chou, Z. Ye, and L. Cheng, "Generation of integration-free human induced pluripotent stem cells from postnatal blood mononuclear cells by plasmid vector expression," Nature Protocols, vol. 7, no. 11, pp. 20132021, 2012.

[134] K. Streckfuss-Bomeke, F. Wolf, A. Azizian et al., "Comparative study of human-induced pluripotent stem cells derived from bone marrow cells, hair keratinocytes, and skin fibroblasts," European Heart Journal, vol. 34, no. 33, pp. 26182629, 2013.

[135] M. Ieda, J. D. Fu, P. Delgado-Olguin et al., "Direct reprogramming of fibroblasts into functional cardiomyocytes by defined factors," Cell, vol. 142, no. 3, pp. 375-386, 2010.

[136] Y. Oda, Y. Yoshimura, H. Ohnishi et al., "Induction of pluripotent stem cells from human third molar mesenchymal stromal cells," The Journal of Biological Chemistry, vol. 285, no. 38, pp. 29270-29278, 2010.

[137] T. Vierbuchen, A. Ostermeier, Z. P. Pang, Y. Kokubu, T. C. Sudhof, and M. Wernig, "Direct conversion of fibroblasts to functional neurons by defined factors," Nature, vol. 463, no. 7284, pp. 1035-1041, 2010.

[138] E. Szabo, S. Rampalli, R. M. Risueno et al., "Direct conversion of human fibroblasts to multilineage blood progenitors," Nature, vol. 468, no. 7323, pp. 521-526, 2010.

[139] P. Huang, Z. He, S. Ji et al., "Induction of functional hepatocyte-like cells from mouse fibroblasts by defined factors," Nature, vol. 475, no. 7356, pp. 386-389, 2011.

[140] M. Stadtfeld, K. Brennand, and K. Hochedlinger, "Reprogramming of pancreatic $\beta$ cells into induced pluripotent stem cells," Current Biology, vol. 18, no. 12, pp. 890-894, 2008. 


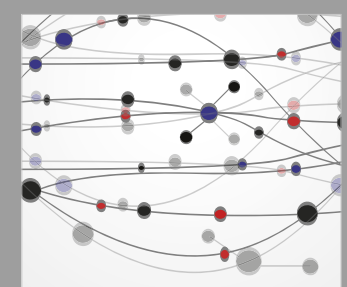

The Scientific World Journal
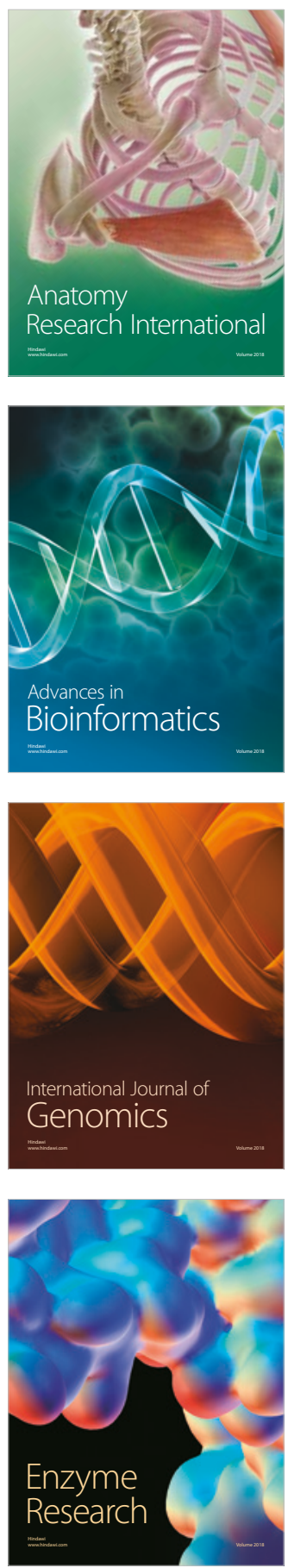
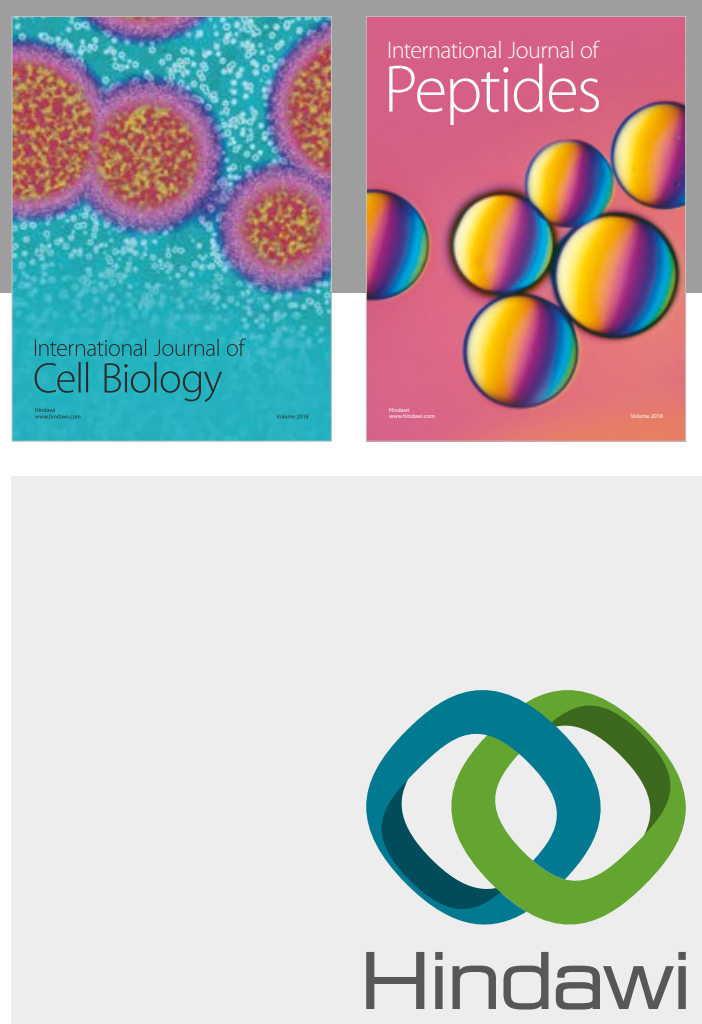

Submit your manuscripts at

www.hindawi.com
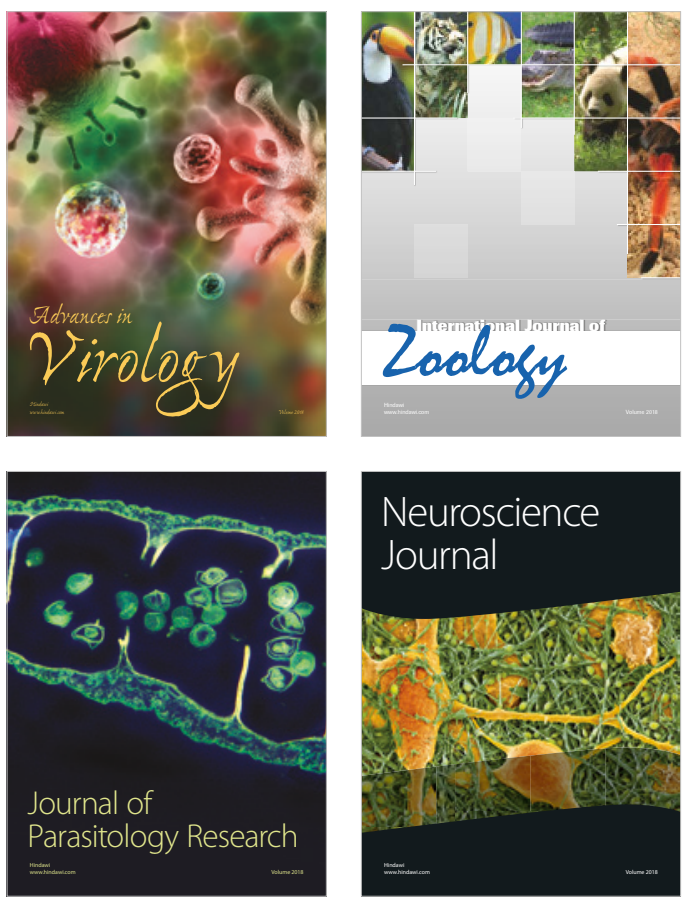
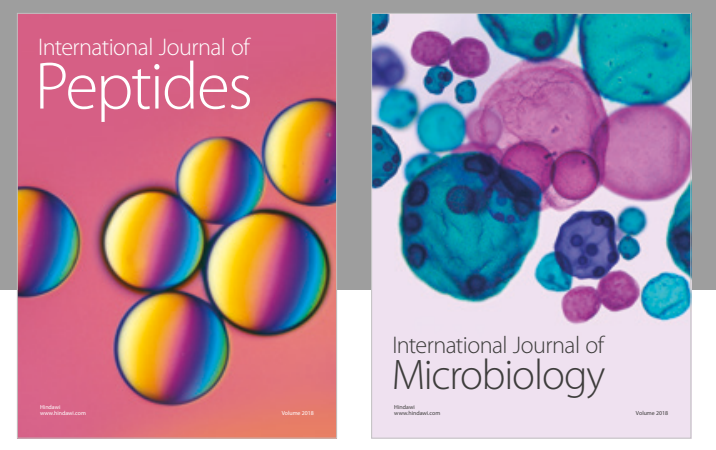

nternational Journal of Microbiology
Journal of
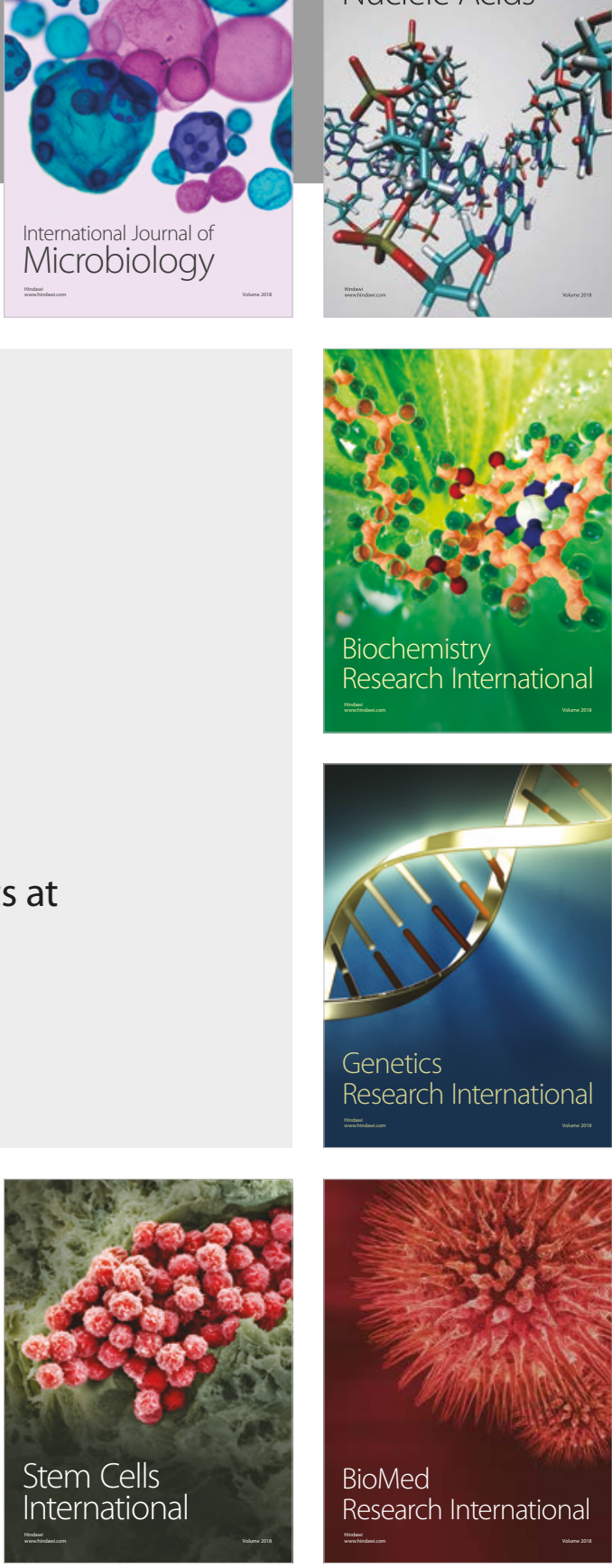
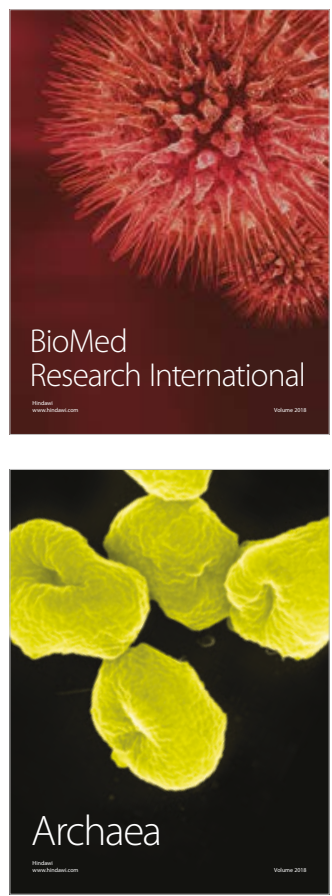